\title{
Invited review: Current representation and future trends of predicting amino acid utilization in the lactating dairy cow
}

\author{
S. I. Arriola Apelo, ${ }^{*}$ J. R. Knapp, † and M. D. Hanigan*¹ \\ *Department of Dairy Science, Virginia Tech, Blacksburg 24060 \\ †Fox Hollow Consulting LLC, Columbus, OH 43201
}

\begin{abstract}
In current dairy production systems, an average of $25 \%$ of dietary $\mathrm{N}$ is captured in milk, with the remainder being excreted in urine and feces. About $60 \%$ of total $\mathrm{N}$ losses occur postabsorption. Splanchnic tissues extract a fixed proportion of total inflow of each essential AA (EAA). Those EAA removed by splanchnic tissues and not incorporated into protein are subjected to catabolism, with the resulting $\mathrm{N}$ converted to urea. Splanchnic affinity varies among individual EAA, from several fold lower than mammary glands' affinity for the branchedchain AA to similar or higher affinity for Phe, Met, His, and Arg. On average, $85 \%$ of absorbed EAA appear in peripheral circulation, indicating that first-pass removal is not the main source of loss. Essential AA in excess of the needs of the mammary glands return to general circulation. High splanchnic blood flow dictates that a large proportion of EAA that return to general circulation flow through splanchnic tissues. In association with this constant recycling, EAA are removed and catabolized by splanchnic tissues. This results in splanchnic catabolism equaling or surpassing the use of many EAA for milk protein synthesis. Recent studies have demonstrated that EAA, energy substrates, and hormones activate signaling pathways that in turn regulate local blood flow, tissue extraction of EAA, and rates of milk protein synthesis. These recent findings would allow manipulation of dairy diets to maximize mammary uptake of EAA and reduce catabolism by splanchnic tissues. Dairy cattle nutrient requirement systems consider EAA requirements in aggregate as metabolizable protein (MP) and assume a fixed efficiency of MP use for milk protein. Lysine and Met sufficiency is only considered after MP requirements have been met. By doing so, requirement systems limit the scope of diet manipulation to achieve improved gross $\mathrm{N}$ efficiency. Therefore, this review focuses on understanding the dynamics of EAA metabolism in
\end{abstract}

Received August 20, 2013.

Accepted March 6, 2014.

${ }^{1}$ Corresponding author: mhanigan@vt.edu mammary and splanchnic tissues that would lead to improved requirement prediction systems. Inclusion of variable individual EAA efficiencies derived from splanchnic and mammary responses to nutrient and hormonal signals should help reduce dietary protein levels. Supplementing reduced crude protein diets with individual EAA should increase gross $\mathrm{N}$ efficiency to more than $30 \%$, reducing $\mathrm{N}$ excretion by the US dairy industry by $92,000 \mathrm{t}$ annually.

Key words: nitrogen utilization, essential amino acid requirement, mammary gland, splanchnic tissue

\section{INTRODUCTION}

Agriculture in general and the dairy industry in particular are under increasing pressure from federal and local governments and from consumers to reduce their environmental footprint. Among the dairy industry pollutants, $\mathrm{N}$ excretion is a major concern because of its impact on air and water quality, ecosystem biodiversity, and human health. Nitrogen export to the environment can result in eutrophication of aquatic ecosystems and coastal hypoxia; increased atmospheric particles, decreased stratospheric ozone concentrations, and greenhouse gas concentrations; increased acidity of precipitation, soil, and surface water; aggravation of asthma in people; and denigration of drinking water contributing to methemoglobinemia in infants (Wolfe and Patz, 2002). In addition to the environmental impact of nitrogen, protein - the source of the waste $\mathrm{N}$-is an expensive dietary nutrient, representing approximately $42 \%$ of the cost of lactating cow rations (St-Pierre, 2012). Improving gross N efficiency would improve dairy economics, reduce environmental impact, and reduce demand for animal feed protein sources.

There are approximately 9 million dairy cattle in the United States (USDA-ERS, 2012). In a survey carried out on 103 large dairies across the country $(613 \pm 46$ cows and $34.5 \pm 0.3 \mathrm{~kg}$ of milk sold per cow per day), nutritionists reported feeding diets that averaged 17.8 $\pm 0.1 \%$ CP (Caraviello et al., 2006). A meta-analysis using 846 experimental diets with similar average $\mathrm{CP}$ content reported a mean gross $\mathrm{N}$ efficiency of $24.7 \pm$ $3.99 \%$ (Hristov et al., 2004b). Thus, over a 10-mo lacta- 
tion, assuming the same dietary conditions $(22.1 \mathrm{~kg} / \mathrm{d}$ DMI and $17.8 \% \mathrm{CP}$ ) reported by Hristov et al. (2004b), 1.3 million tonnes of dietary $\mathrm{N}$ would have been excreted in the United States.

To reduce the environmental impact of the dairy industry, it is necessary to know the potential maximal gross $\mathrm{N}$ efficiency for milk protein production, where $\mathrm{N}$ is lost, and what approaches can be used to mitigate those losses and improve gross $\mathrm{N}$ efficiency. Dietary $\mathrm{N}$ that is not incorporated into milk is mostly excreted in feces or urine. Fecal $\mathrm{N}$ includes undigested dietary, microbial, and endogenous N. The latter represents between 18 and $31 \%$ of fecal $\mathrm{N}$ and includes undigested proteins secreted along the gut, sloughed cells from the gut mucosa, and urea recycled to the hindgut (Lapierre et al., 2008; Røjen et al., 2012), which are not particularly responsive to varying dietary N levels. Similarly, intestinal digestibility of bacterial protein and RUP from individual ingredients is considered fixed by nutrient requirement systems (NRC, 2001).

Unlike fecal $\mathrm{N}$, urinary $\mathrm{N}$ excretion is highly responsive to varying $\mathrm{N}$ intake (Lobley et al., 2000a; Lapierre and Lobley, 2001; Reynolds and Kristensen, 2008). When dietary $\mathrm{N}$ is not highly restricted, most of the urinary $\mathrm{N}$ is excreted as urea produced in the liver from 2 sources: ruminal ammonia and postabsorptive AA catabolism (Lobley et al., 2000b; Marini and Van Amburgh, 2003). At low levels of N supply, other sources of $\mathrm{N}$ such as ammonia can represent a significant proportion of total $\mathrm{N}$ excreted in urine and can even surpass the amount of $\mathrm{N}$ excreted as urea (Wickersham et al., $2008,2009)$. The relative contribution of rumen ammonia and postabsorptive AA catabolism to the total amount of urea produced in the liver depends on how well the $\mathrm{N}$ supply matches ruminal and postabsorptive requirements. When RDP was supplemented in excess of the microbial utilization capacity, ammonia absorption from the rumen and $\mathrm{N}$ excretion in urine increased (Hristov et al., 2004a). Thus, excess RDP reduces gross $\mathrm{N}$ efficiency, but the efficiency of MP for milk protein synthesis (MPLE) does not change (Cyriac et al., 2008). On the other hand, increasing RUP supply increases duodenal absorption of both EAA and NEAA, and when the absorbable supply of AA exceeds MP requirements for maintenance, lactation, gestation, and growth, excess AA are catabolized, increasing N excretion in urine. Therefore, by matching MP supply with maintenance and production requirements, MPLE should be maximized, and urea production and urinary $\mathrm{N}$ excretion should be minimized. However, even when MP just meets requirements, some EAA are likely limiting, whereas other EAA are provided in excess of their individual requirements and are subject to catabolism. This latter group represents an inefficiency.
Swine and poultry nutritionists formulate rations with reduced protein levels and supplement with specific EAA to minimize overfeeding of most EAA. Using this approach results in gross $\mathrm{N}$ efficiencies of $40 \%$ or greater (Nahm, 2002). Baker (1996) made maximal use of this strategy and demonstrated that postabsorptive $\mathrm{N}$ efficiency in pigs can reach $85 \%$ when the supply of each EAA matches tissue needs. That efficiency is in agreement with the maximal theoretical efficiency of the mammary glands (MG) to convert an ideal absorbed EAA profile into milk protein, as considered by the UK Nutrient Requirement System for Ruminants (AFRC, 1992). Dijkstra et al. (2013) discussed potential losses that explain why maximal theoretical partial efficiencies cannot be achieved at the animal level. The inevitable losses included endogenous $\mathrm{N}$ losses in urine and feces, microbial nucleic acids, undigested AA, and catabolism of absorbed AA (Dijkstra et al., 2013). However, reducing dietary CP to $15 \%$ or lower and supplementing with individual EAA should increase gross $\mathrm{N}$ efficiency to $30 \%$ or greater (NRC, 2001; Haque et al., 2012) and reduce $\mathrm{N}$ losses by 92,000 $\mathrm{t} / \mathrm{yr}$ in the United States. If such a reduction in dietary protein could be achieved industry-wide with no loss in production, the reduction in need for high-protein meal ingredients translates to 543,000 fewer hectares of land used to grow soybeans, assuming a yield of 2,700 $\mathrm{kg} / \mathrm{ha}$ (NASS, 2013). Feeding such low levels of dietary protein requires very accurate and precise predictions of nutrient requirements to avoid potential losses in milk production and dairy income. Therefore, the focus of this review is on experimental and modeling work investigating MG and splanchnic metabolism of EAA, as well as their effect on cell signaling regulation of milk protein synthesis. The objective is to delineate modeling approaches that will address the current deficiencies and lead to model systems that can be used to increase postabsorptive MPLE.

\section{CURRENT REPRESENTATION OF EAA SUPPLY AND REQUIREMENTS}

The National Research Council (NRC, 1989, 2001) equations, especially the postabsorption protein system, are used in whole or in part by most ration balancing software packages in the United States. Thus, components of the protein system encoded in the Dairy NRC $(1989,2001)$ models (the latter being referred to as NRC-2001 for the remainder of this work) are used to determine protein supplementation in most US dairy diets. The NRC-2001 predicts flow of MP and digestible EAA to the small intestine. Requirements for MP are determined based on efficiencies dependent on the metabolic process (i.e., maintenance, lactation, growth, 
and gestation). Specific requirements for Lys and Met are also established in NRC-2001, but these are assessed as a proportion of total MP required. This negates the need to know the exact amount of each EAA required, yet provides a method to identify EAA that are likely limiting in a ration based on their proportions in MP. However, establishing EAA requirements as a proportion of MP does not allow manipulation of EAA amounts separately to reduce total MP supply below requirements and supplement with individual EAA. Furthermore, splanchnic and MG fractional removal (uptake as a percentage of supply) of individual EAA differ among the AA (MacRae et al., 1997b; Hanigan et al., 2001, 2004a; El-Kadi et al., 2006). Finally, mammary fractional removal of individual EAA can be affected by arterial supply of those and other EAA (Bequette et al., 2000; Hanigan et al., 2002). The combination of these undermines the effectiveness of treating them in aggregate as MP. Thus, attempting to define AA requirements in aggregate or even as a fixed proportion of MP will likely over-predict requirements for some EAA and under-predict requirements for other EAA under some conditions.

The NRC-2001 predicts intestinal digestibility of RUP based on digestion coefficients for the protein in each feed ingredient. Microbial protein digestibility in the small intestine is assumed to be, in a percentage base, $80 \%$. Microbial protein and RUP coefficients are used by NRC-2001 to empirically predict the proportions of EAA in MP. Evaluation of those assumptions by comparison of predictions of individual digested EAA with the corresponding net portal appearance of EAA absorption resulted in predictions with reasonably small errors (Pacheco et al., 2006), suggesting that the approach works within the range of observed data.

The effort to predict intestinal flow of individual EAA by NRC-2001 was not fully leveraged in the postabsorptive model as AA requirements for milk production are primarily restricted to MP supply, with only Lys and Met identified as potential AA limiting protein yield based on percentages in MP (NRC, 2001). Haque et al. (2012) observed an increase in milk production, milk protein yield (MPY), and MPLE when lactating Holstein cows (179 DIM) consuming a diet with either $7.7 \% \mathrm{MP}$ of the DM or $9.6 \% \mathrm{MP}$ of the DM were duodenally infused with an EAA mix (His, Leu, Lys, and Met). The response to the EAA infusion was independent of MP supply, indicating that one or more of those EAA were still limiting production, even at the higher level of dietary MP. An MP-based model such as NRC-2001 is unable to predict the response observed by Haque et al. (2012) because it does not consider individual EAA requirements in terms of grams per day.
The NRC-2001 model assumes that the MP supply is first used to meet maintenance requirements, which are a function of BW (endogenous urinary and scurf proteins) and DMI (endogenous MP and metabolic fecal protein). The remainder is used for productive functions such as gestation, growth, and milk protein synthesis. When the cow is not pregnant or growing and once maintenance requirements are met, MP is used with $67 \%$ efficiency for milk protein synthesis (MPLE). The model assumes the same efficiency above requirements but does not attempt to predict the maximal productive capacity of the cow. Thus, MPLE above requirements may still be $67 \%$ or it may be $0 \%$ if, given a level of intake, energy is limiting milk production because NRC-2001 does not accommodate additive nutrient effects. When cows are producing somewhere between 0 and the maximum level of production, the MPLE used in the model is significantly greater than observations reported in the literature (Hanigan et al., 1998a; Hristov et al., 2004b; Lapierre et al., 2010). In an evaluation of the NRC-2001 model using 100 treatment means from 25 published studies (Figure 1), $82 \%$ of the observations had milk yields lower than the predicted MP-allowable milk (NRC, 2001). The slope of residuals regressed on predicted values was -0.34 , indicating an over-estimation of the MPLE (most of the variation on MPY is explained by variation in milk yield, not in milk protein percentage). Therefore, the average MPLE for lactation is approximately $44 \%[0.67 \times(1-$ $0.34)$ ]. A quadratic term can be fitted to the residuals also, suggesting that MPLE decreases as MP supply increases. The authors identified energy and individual EAA as the nutrients most likely to limit milk production (NRC, 2001). The reason for adopting higher MPLE than those observed empirically may have to do with the compartmental representation of maintenance requirements of the model and the assumption of fixed MPLE. The NRC-2001 subtracts maintenance requirements from supply before determining the amount of milk protein that can be produced from MP. Thus, MPY is 0 until MP intake exceeds maintenance MP requirements. Any error in estimating the maintenance requirement will affect the estimate of MPLE, because the latter can only be derived from observing gross efficiency of lactating cows. Additionally, any curvilinearity to observed MPLE will contribute to overestimates of predicted MPLE when a linear function is used. To fit observations at low MP supply levels, the slope has to be high, which will result in overpredictions of the response to MP close to lactation requirements when MPLE is declining (Hanigan et al., 1998a). That pattern is observed in Figure 1, where residuals are more evenly distributed at low prediction levels. Overpre- 


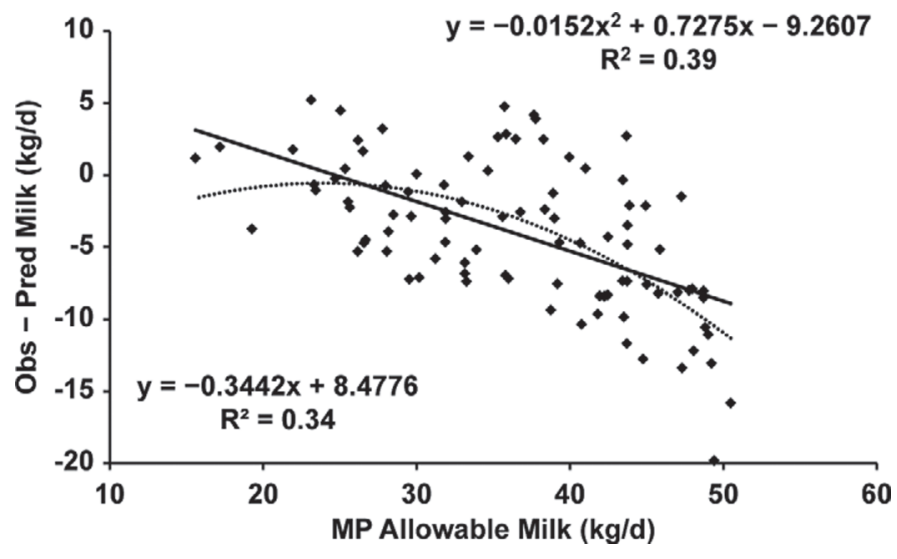

Figure 1. Milk (kg/d) residual errors (observed - predicted; Obs - Pred) as function of MP-allowable milk ( $\mathrm{kg} / \mathrm{d})$ supply. Points represent individual residuals, the solid line represents the predicted linear function of those residuals, and the dashed line represents a predicted quadratic function. Adapted from Figure 16.3 in NRC (2001). Data from 25 published studies summarizing 100 treatment means.

dicting MPY at MP levels close to requirement has a larger negative economic and environmental impact than prediction errors at low MP supply levels because the former is the range where most commercial dairy diets are formulated.

Additional evidence that MLPE should not be fixed is provided by selected experimental observations. In a conclusive study, Whitelaw et al. (1986) observed that abomasal infusion of $200 \mathrm{~g} / \mathrm{d}$ of casein to Ayrshire cows in early lactation (20 DIM) fed a $13.6 \% \mathrm{CP}$ diet and producing $13 \mathrm{~kg} / \mathrm{d}$ of milk increased milk production by $2.3 \mathrm{~kg}$ with an MPLE of $41.5 \%$. Because the cows were already producing milk on the basal diet (13.6\% $\mathrm{CP})$ none of the additional infusate should have been required for maintenance, based on NRC-2001 assumptions. Infusing an additional $200 \mathrm{~g}$ of casein/d (400 $\mathrm{g} / \mathrm{d}$ total) increased milk production by another 1.2 $\mathrm{kg} / \mathrm{d}$ and MPLE for this second increment decreased to $22.6 \%$. Infusion of an additional $200 \mathrm{~g}$ of casein/d (600 $\mathrm{g} / \mathrm{d}$ total) increased milk production by $0.7 \mathrm{~kg}$, and MPLE for this final increment was only $15.4 \%$. Because the cows responded to all levels of supplementation, they clearly did not exceed their genetic potential for the first 2 infusion levels, yet neither infusion resulted in marginal efficiencies close to the $67 \%$ assumed by NRC2001. Additionally, MPLE was clearly variable in relation to MP supply. Looking at a wider range of dietary CP levels (11.3 to $20.1 \% \mathrm{DM}$ ), a quadratic response in MPY was observed, indicating that MPLE decreases as supply increases (Metcalf et al., 1996b). Increasing dietary CP content from 13.5 to $19.4 \%$ of DM for midlactation (120 DIM) Holstein cows had no effect on MPY and thus resulted in a decrease in MPLE (Olmos Colmenero and Broderick, 2006). Recently, Metcalf et al. (2008) evaluated the accuracy of the $68 \%$ MPLE adopted by the UK requirement system (AFRC, 1992) in lactating cows fed at 4 different $\mathrm{CP}$ levels $(12.5 \%$ and $25 \%$ below and above requirements). In the Whitelaw et al. (1986) work, increased MP supply was observed to reduce MPLE. However, when estimating MPLE, the authors forced the regression intercepts to zero; that is, no milk production when MP supply was at or below maintenance. If MPLE is curvilinear with respect to supply, as indicated by variable MPLE, using a linear regression model and forcing a zero intercept will severely bias slope estimates for the nonlinear portions of the curve. The derived slopes will, at best, represent the average marginal responses from maintenance to the level fed (assuming the maintenance estimate is accurate), which is geometrically represented by the slope of the arc segment of the curve. In fact, the instantaneous response at each MP level, which is represented by the slope of the tangent, represents the true MPLE. The tangents can have a wide range of intercepts depending on the amount of curvature, so the intercepts must be derived with the slopes. Furthermore, it is the slope of the tangent (MPLE) that determines the profitability of increasing or reducing MP supply. An approximation to the true MPLE in the Metcalf et al. (2008) study would be the marginal efficiency of each increment of protein added to the diet. Using this approach, MPLE decreased from a high of $35 \%$ when MP increased from -25 to $-12.5 \%$ of milk protein requirements to a low of $18 \%$ when MP supply increased from +12.5 to $+25 \%$ of milk protein requirements. These MPLE are similar in range to those observed by Whitelaw et al. (1986).

Model aggregation at the protein level has the added limitation of forcing requirements to be set high enough to supply adequate amounts of the EAA with the lowest efficiency for milk protein, while EAA with higher efficiency are supplied in excess. Using the same model framework and assumptions as for MP requirements will likely result in an inadequate model, given observations at the cellular (Appuhamy et al., 2011, 2012) and whole-animal levels (Rius et al., 2010; Toerien et al., 2010; Haque et al., 2013). These observations indicate that energy supply, hormone concentrations, and select individual EAA all have independent and additive effects on milk protein synthesis and on MPLE. As these additive and independent effects are inconsistent with the current framework of assuming a single limiting AA, we must re-examine our knowledge base with the goal of developing a better presentation of the true biology.

\section{SPLANCHNIC EAA METABOLISM}

Figure 2 presents $\mathrm{N}$ fluxes $(\mathrm{g} / \mathrm{d})$ in lactating cows fed a low (15\%) protein diet (Hanigan et al., 2004b). It 


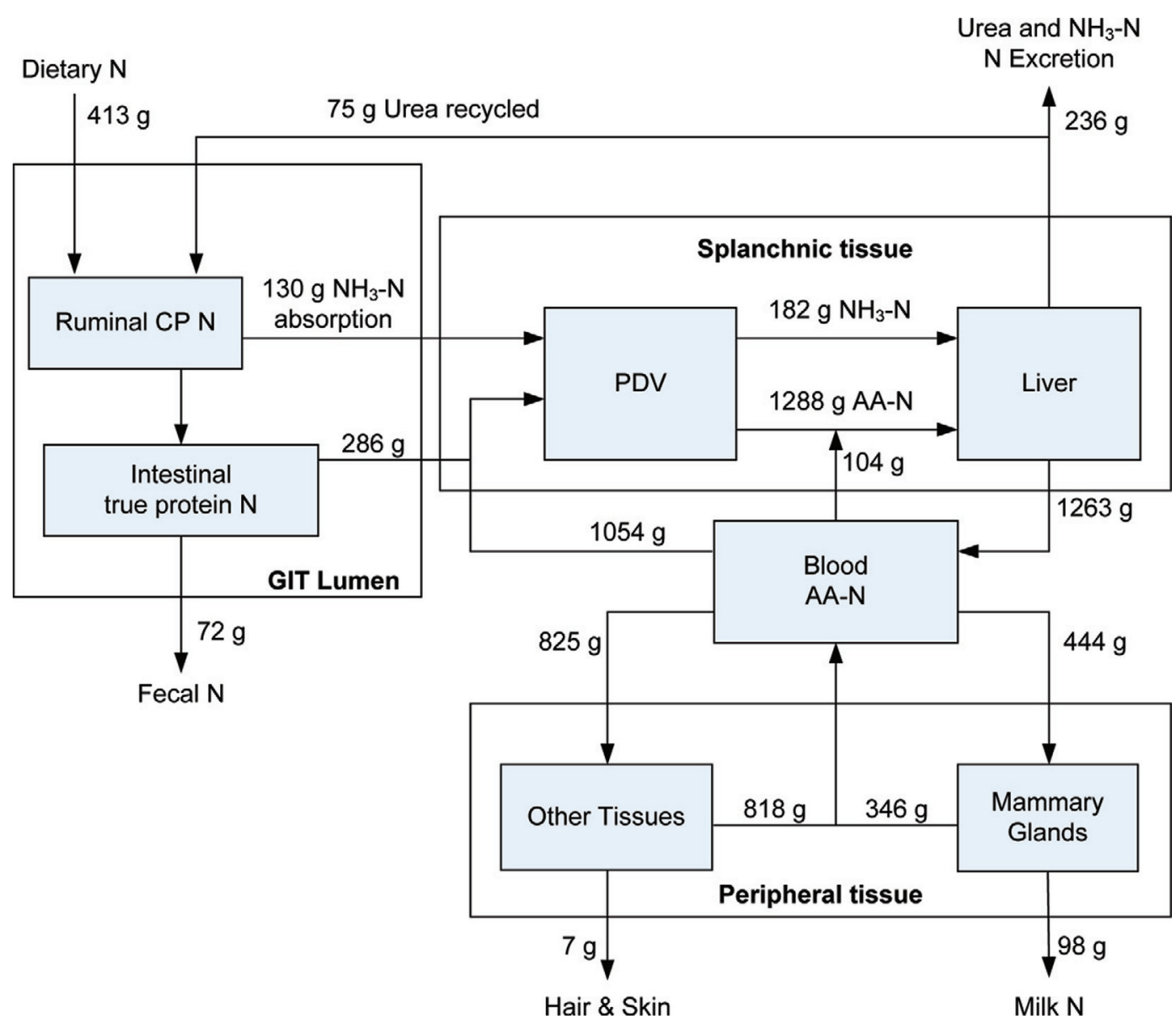

Figure 2. Nitrogen flux diagram derived from Hanigan et al. (2004b), control treatment ( $0 \mathrm{~g} / \mathrm{d}$ of casein infused). Solid boxes represent pools, open boxes represent compartments, and numbers indicate fluxes ( $\mathrm{g}$ of N/d). GIT = gastrointestinal tract; PDV = portal-drained viscera. Intestinal AA flux was obtained from NRC (2001). Urine and fecal N excretion, and other tissue N losses were calculated by difference. Color version available in the online PDF.

is important to note that the diagram represents total AA-N. Individual EAA fluxes depend on splanchnic and mammary affinity, which vary among EAA and on dietary treatment. In this example, postabsorptive mean $\mathrm{N}$ efficiency for milk protein (without consideration of maintenance cost) was $34 \%$. Mammary fractional removal of AA-N was $22 \%$, and for splanchnic tissue it represented $12.5 \%$ of total supply (arterial influx and absorption). Although other peripheral tissues remove some absorbed EAA, partially represented in the diagram, such use is a minor proportion of the total AA-N absorbed and not incorporated into milk protein. Splanchnic blood flow is between 3 and 4 times MG blood flow (Delgado-Elorduy et al., 2002; Hanigan et al., 2004b; Raggio et al., 2004). Thus, AA-N influx to splanchnic tissues is significantly larger than that to the MG, and splanchnic net removal can equal or surpass incorporation into milk protein for most of the EAA (Arg, His, Met, Phe, Thr, and Trp; Hanigan et al., 2001, 2004a,b). This analysis demonstrates that effects of splanchnic metabolism are primarily a function of the EAA released by the MG and other tissues, and not a function of first-pass removal (i.e., the tissue bed is a responder not a driver), and this response is not captured by a model with fixed MPLE.

Before delving into the topic further, a brief discussion of the calculations typically used to assess tissue affinity for AA is warranted. This discussion is pertinent to splanchnic tissues as well as the MG and other peripheral tissues. Fractional removal, calculated as the ratio of arterio-venous difference by arterial concentration, completely ignores the effect of blood flow. Even when total influx and outflux are considered for the calculation, blood flow entering and leaving the organ are the same (milk volume is dismissible compared with mammary blood flow) and cancel out. This calculation has historically been used to represent relative tissue affinities among nutrients or between tissues for a given 
nutrient. However, the use of fractional removal to assess changes in intrinsic tissue affinity has 2 major limitations that should discourage scientists from using them for this purpose. First, venous concentrations more closely represent extracellular concentrations than arterial. Diffusion of small molecules such as AA from the capillaries to the extracellular space is as rapid as arterial inflow (Farr et al., 2000), ensuring that capillary and extracellular spaces are very close to a perfectly mixed pool. If no other sources of blood enter the pool or are mixed with venous outflow before measurement, then venous outflow must be equivalent to source pool concentrations; that is, the well-mixed extracellular plus capillary space. Thus, the AA transporters on the cell membrane are exposed to AA concentrations that are approximated by venous concentrations, not arterial (Hanigan et al., 1998b). Second, increasing total influx through changes in blood flow also increases removal of metabolite in venous blood. More blood flow will increase metabolite input to the tissue but will also remove metabolite. Thus, equal increases in metabolite input by a change in arterial concentration or a change in blood flow will not yield equal uptake changes by the tissue unless tissue affinity is so high that essentially all of the input metabolite is cleared by the tissue. The lower the tissue affinity, the greater the divergence between concentration and blood flow responses. This latter concept is totally ignored when calculating fractional removal (Hanigan et al., 1998b). Thus calculating fractional removal based only on arterial concentration fails to account properly for the true substrate concentrations at the cell surface and the nonlinear effects of changes in blood flow on those concentrations, and these methods of calculation should not be used to infer intrinsic tissue activity.

Clearance rate constants as derived by Hanigan et al. (1998b) from the product of venous blood flow and the ratio of arterio-venous difference and venous concentration are independent of concentration and flow and thus, better represent the tissue activity. In defining this model, Hanigan et al. (1998b) only assumed that capillary concentrations equal interstitial concentrations, extracellular concentrations are linearly proportional to the intracellular pool, and that the pools rapidly achieved steady state. As noted above, the first is clearly the case. Work on transport activity has demonstrated that intracellular and extracellular pools are proportional (Clark et al., 1980). Finally, the flux through the pools is so large that turnover rates range from the high seconds to low minutes range, ensuring that the system will be in steady state except over very brief periods after a change in inputs.

Unfortunately, fractional removal has been used and reported extensively in the literature and one must rely on those values when interpreting all available data. In general, the direction of change inferred from both should be correct provided blood flow does not change.

Even if the EAA profile of the protein digested in the small intestine perfectly matched the milk protein profile, variable splanchnic affinities for individual EAA will modify flow of those EAA to the MG, and the MG will modify the flow of individual EAA returning to splanchnic tissues. Figure 3 shows portal-drained viscera (PDV), liver, and MG affinities for individual EAA from modeling work in those tissues (Hanigan et al., 2001, 2004a,b). The ratio between splanchnic and mammary affinity for individual EAA weighted by tissue blood flow will in turn determine circulating EAA concentrations, fractional incorporation into milk protein, and excretion. The different affinities between tissues and among EAA reported in Figure 3 cannot be captured by a model that aggregates individual EAA into a unique postabsorptive pool.

\section{PDV Metabolism of EAA}

Assuming gut growth is quantitatively insignificant in the lactating cow after the large increases in DMI in early lactation, net EAA use by the PDV should be reduced to 3 main components: synthesis of export proteins, replenishment of sloughed cells, and energy supply from carbon skeletons. Export protein synthesis is estimated to represent between 0 and $50 \%$ of total endogenous $\mathrm{N}$ losses, with the remainder represented by sloughed cells (Lapierre et al., 2008). Catabolism of EAA for energy generation in ruminant PDV seems to be limited to the branched-chain AA (BCAA), Met, and, among NEAA, Glu and Gln (Lobley et al., 2003;

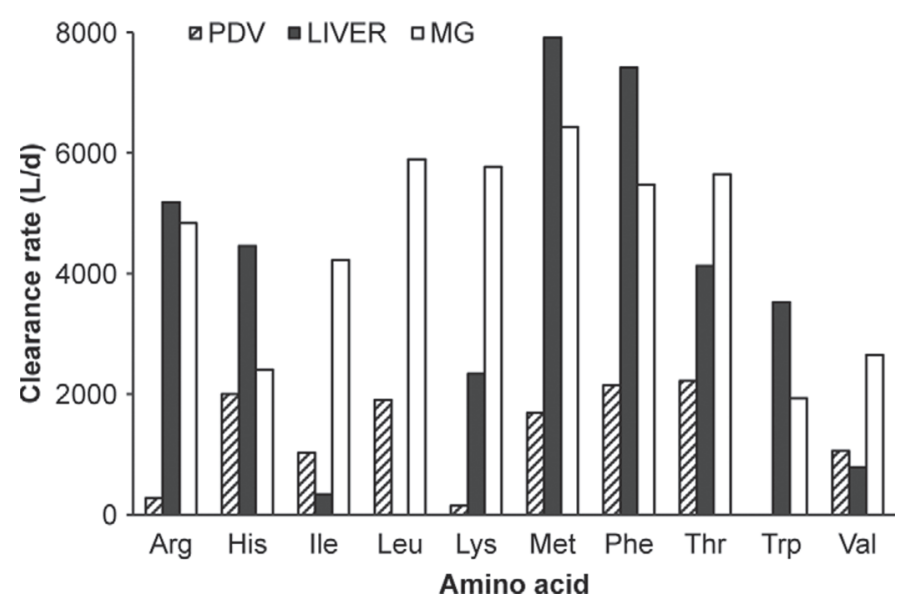

Figure 3. Portal-drained viscera (PDV), liver, and mammary glands (MG) clearance rate constants (L/d) as derived by Hanigan et al. (2001, 2004a,b). Leucine liver constant and Trp PDV constant are not reported. 
El-Kadi et al., 2006). In sheep infused with labeled Leu in the small intestine, catabolism accounted for $21 \%$ of the Leu removed by the PDV (MacRae et al., 1997a). However, despite its relevance for EAA metabolism, catabolism of EAA and NEAA is insignificant in sparing the use of glucose by the PDV (El-Kadi et al., 2006; Doepel et al., 2007; Larsen and Kristensen, 2009).

Among the factors that could affect PDV use of individual EAA are intestinal absorption rates, arterial plasma concentrations, and blood flow. In addition, cellular EAA availability could be limited by individual EAA transport capacity from blood or the intestinal lumen. However, net removal seems to be linear (mass action) over a wide range of arterial concentrations for individual EAA (Hanigan et al., 2004b; Raggio et al., 2004; El-Kadi et al., 2006). Thus, saturation of individual EAA transporters does not appear to be a limitation, and total supply (arterial plus intestinal) should drive PDV net removal. In sheep infused with labeled Leu in the small intestine and jugular vein, PDV fractional removal of intestinal plus arterial influx of EAA ranged from about $20 \%$ for Leu, Lys, and Val to $5 \%$ for Phe and His as a proportion of arterial plus intestinal supply (MacRae et al., 1997a). The fraction removed from the intestinal supply was between 60 and $500 \%$ larger than that from the arterial supply, suggesting that preferential use of luminal AA occurred. However, net uptake of EAA (BCAA, His, Lys, and Thr) from arterial sources was $80 \%$ of total tissue uptake, except for Phe, where intestinal and arterial sources contributed similarly (MacRae et al., 1997a). In dairy cows, PDV clearance rate constants were highest for Thr, Phe, Leu, and His, intermediate for Val and Met, and lowest for Lys and Arg (Figure 3; Hanigan et al., 2004b). Label sequestration of EAA infused into the jejunum or jugular vein was highly correlated with EAA composition of PDV protein, indicating high protein turnover rates and suggesting that the measurements largely reflected label sequestration in protein (MacRae et al., 1997a). Essential AA sequestered in PDV structural protein would be matched by equal amounts of EAA released from protein in association with protein turnover; thus, such use does not represent a net loss of AA. This consideration is required when analyzing labeled sequestration, and researchers must rely on net balance measurements to estimate tissue use and affinity. Net balance data indicate that recycling of EAA from peripheral tissues is the main supplier of EAA removed by the PDV (Hanigan et al., 2004b). Given the relatively low PDV affinity for individual EAA, supplementing MP above requirements would increase EAA flow into the portal vein. Essential AA not removed by the liver or peripheral tissues return to general circulation, and a large proportion of that recycles back to
PDV in arterial blood where a fraction of it (5-20\%) would be sequestered in each pass.

Given that arterial blood is the main supplier of EAA to the PDV, increased blood flow would increase total supply, and one might assume removal of EAA (Hanigan et al., 2004b). However, as the PDV is a net exporter of EAA, increased blood flow also increases the rate of removal in the portal vein, thus reducing interstitial and portal EAA concentrations. Therefore, increased portal blood flow should reduce the rates of removal of arterial EAA (Hanigan et al., 2004b). Blood flow in the portal vein responds to energy supply (Lomax and Baird, 1983; Reynolds, 1995) but not to protein supply (Hanigan et al., 2004b; Raggio et al., 2004). Hence, the increases in blood flow mediated by energy supply should increase the release rates of EAA to the portal vein. This hypothesis was not substantiated in the study of Larsen and Kristensen (2009), where glucose infusion reduced EAA appearance in the portal vein. However, in that study, portal blood flow was not reported, and glucose infusion significantly reduced diet intake, likely reducing EAA flow to the small intestine. More research is required to understand nutrient effects on blood flow and the effects of blood flow on PDV metabolism of nutrients.

\section{Liver Metabolism of Essential AA}

Liver extraction and metabolism of EAA have been reviewed (Hanigan, 2005; Lapierre et al., 2005). Hanigan et al. (1998b, 2004a) represented liver net removal of EAA as a mass action function of total supply (bidirectional exchange across the cell membrane was not represented). There were no indications that clearance rate constants varied as AA supply was altered in the early work. Raggio et al. (2004) subsequently reported an increase in fractional removal for Met, Phe, and Tyr as dietary MP was increased, raising questions as to the constancy of hepatic removal with respect to MP supply.

Excepting the BCAA where hepatic clearance rates are very low, hepatic clearance rates of EAA range from a low of $41 \%$ of mammary clearance rate for Lys to a high of $135 \%$ for Phe (Hanigan et al., 2001, 2004a). However, because hepatic blood flow is 3- to 4-fold greater than mammary blood flow, the fractional removal of EAA by the liver is lower. It should be noted that comparison of hepatic and mammary affinities in this review deviates from the review of Hanigan (2005), where it was concluded that mammary affinity was much greater than liver affinity. In reviewing the source data used for the earlier review, it is clear that a mistake was made in calculating the mammary clearance rates in the earlier work. The values reported in this work are representative of the source work. 
High hepatic blood flow dictates that the majority of EAA reaching the liver are delivered from arterial supplies (arterial delivery in PDV plus arterial delivery in the hepatic artery), and thus net uptake of EAA by the liver is largely a function of recycling from peripheral tissues. Nutritionally, this is an opportunity because providing energy or signaling AA that are minimally removed by the liver, such as BCAA, could stimulate protein synthesis in MG, increase mammary net uptake of other EAA (e.g., Met), and reduce EAA recycling to splanchnic tissues, liver net clearance, and EAA catabolism.

Several studies have found no effect of MP supply on hepatic blood flow (Blouin et al., 2002; Hanigan et al., 2004b; Raggio et al., 2004), whereas energy supply has been shown to be positively associated with changes in hepatic blood flow (Lomax and Baird, 1983; Reynolds, 1995). The ability to increase energy supply to the animal without experiencing a significant increase in splanchnic clearance of EAA is consistent with ensuring that the animal can enhance milk output when dietary energy supply is high without compromising posthepatic EAA supply.

In summary, splanchnic tissues play a significant role in metabolism of EAA. More importantly, the effects of PDV and the liver on peripheral availability are unique to each EAA, restricting the utility of prediction models that aggregate EAA in one fraction (MP). The largest fraction of EAA catabolized by splanchnic tissues arises from recycling from peripheral tissues. Therefore, increasing MG demand for individual EAA would sequester more EAA in milk protein at the expense of splanchnic catabolism, thus improving MPLE and reducing $\mathrm{N}$ excretion.

\section{UTILIZATION OF EAA BY THE MAMMARY GLANDS}

Mammary net uptake of individual EAA is a function of arterial influx and cellular transport activity. The former is a function of rates of absorption from the gut, blood flow distribution, and AA transport activity in various tissues (Hanigan et al., 1998a). Mammary unidirectional transport rates $(\mathrm{mol} / \mathrm{d})$ of individual EAA into mammary epithelial cells depend on total influx $(\mathrm{mol} / \mathrm{d})$ of that EAA from arterial blood into the extracellular space and influx of other AA transported by the same AA transport system (Baumrucker, 1985). However, AA competition for transporters seems to have minimal effects on transport rates because most transport systems are operating at rates that are an order of magnitude below their Michaelis-Menten affinity constants (Baumrucker, 1985; Hanigan et al., 1992). Thus, unidirectional transport of individual EAA into mammary epithelial cells seems to be driven by mass action, within ranges observed in lactating cows fed a regular dairy diet, and net mammary uptake of individual EAA would be driven by venous concentrations and blood flow (Baumrucker, 1985; Hanigan et al., 1998b).

\section{Mammary Metabolism of EAA}

Mammary fractional removal of individual EAA changes with arterial concentration (Bequette et al., 2000; Doepel et al., 2004), physiological condition (Schwab et al., 1992), and hormonal status (Mackle et al., 2000). In multiparous lactating Holstein cows, mammary fractional removal of $\mathrm{AA}$, on a percentage basis, ranged from $5 \%$ for Asp to $69 \%$ for Phe (Hanigan et al., 1992). The average fractional removal for EAA was $43 \%$, and for NEAA was $30 \%$ (Hanigan et al., 1992).

Bequette et al. (2000) observed a 43-fold increase $(0.14$ to $6.05 \mathrm{~L} / \mathrm{d})$ in the mammary clearance rate constant for His when arterial His concentration was reduced by $90 \%$ in lactating goats fed a $10.5 \% \mathrm{CP}$ diet and infused with an EAA mixture devoid of His. Clearance rate constants for Lys, Phe, Thr, Val, and the NEAA Pro and Ala were significantly reduced by the His-depleted treatment. That effect was not observed in lactating cows fed $16 \% \mathrm{CP}$ and arterially infused for 10 $\mathrm{h}$ with $30 \mathrm{~g} / \mathrm{h}$ of AA mix with or without His (Cant et al., 2001). However, His arterial concentrations in the His-depleted infusion treatment did not differ from the control (saline infusion), and MPY was similar for the control and the complete AA infusion, suggesting that dietary His was sufficient. Abomasal infusion of casein plus BCAA (500 and $88 \mathrm{~g} / \mathrm{d}$, respectively) to lactating cows fed above MP requirements reduced fractional removal of Val (Mackle et al., 2000). In the same study, insulin (hyperinsulinemic-euglycemic clamp) increased mammary blood flow and fractional removal of the BCAA, Lys, and Arg. Calculation of clearance rate constants from treatment means supports the authors' conclusion that tissue affinity for those AA increased significantly. Therefore, although fixed clearance rates explained mammary net uptake of EAA in cows with small to moderate perturbations of supply (Hanigan et al., 2002), it does not completely represent the biology of the system and fails when challenged with data from animals where large perturbations in the system have been imposed, such as in the work of Bequette et al. (2000). In fact, a Michaelis-Menten representation of mammary net uptake of EAA reduced prediction errors compared with a mass action representation (Bequette et al., 2000; Hanigan et al., 2000).

Net clearance rates are a function of unidirectional transport rates, which depend on the number of epithelial cells and the bidirectional transport activities 
of those cells. The number or differentiation of cells is not likely to explain short-term changes in transport rates observed in association with abomasal or arterial EAA infusions (Akers, 2002). Unidirectional transport of EAA across the epithelial cell membrane is generally an active process that depends on the number of transporters located in the membrane and transport kinetics. Short-term responses in transport rate are related to relocation of AA transporters from intracellular compartments to the plasma membrane, whereas long-term adaptations are a result of gene expression changes for individual transporters (Mackenzie and Erickson, 2004).

At least 10 AA transport systems are expressed by mammary epithelial cells (Baumrucker, 1985). Tight regulation of AA transport system A has been observed in relation to intracellular AA concentrations and insulin signaling in other tissues (Mackenzie and Erickson, 2004). In mammary cells, insulin increased the expression of the $\mathrm{y}^{+}$transporter gene (Menzies et al., 2009), and prolactin seemed to affect transport activity of systems A and L (Shennan et al., 1997). Figure 4 depicts gene expression regulation of proteins belonging to several AA transport systems (SNAT-2, CAT-1, LAT1, and EAAT). These genes have been shown to respond to intracellular AA concentrations through the integrated stress response (ISR) pathway (Kilberg et al., 2005). The same pathway has been shown to stimulate protein translation initiation in liver (Anthony et al., 2004), and is active in mammary epithelial cells (Arriola Apelo et al., 2010; Toerien et al., 2010). In human skeletal muscle, Leu supply stimulated Leu transport into the cell by upregulating mRNA and protein expression of system L (Drummond et al., 2010). The authors suggested an effect of mammalian target of rapamycin complex 1 (mTORC1) on AA transporter gene expression (Drummond et al., 2010). These observations, if confirmed, provide a link between cellular AA demand and supply. However, more research is needed to understand and connect local mechanisms of regulation of EAA removal by the MG with milk protein responses. That knowledge would allow formulation of equations that could accurately predict variations observed when the supply of individual AA is affected. However, the applicability of an individual AA based model will depend, in the end, on whether the protein synthesis machinery in the mammary cells is responsive to changes in the supply of individual EAA.

\section{Mammary Cell Demand and Nutrient Signaling}

Coordination of mammary AA removal with cellular demand helps prevent wasteful energy expenditure associated with AA transport, ribosome biogenesis, and translation. Protein synthesis is tightly regulated at the transcriptional and translational levels. Positive stimuli that increase protein synthesis rates have a negative effect on intracellular free AA concentrations and transfer (t)RNA loading (Elf et al., 2003). Therefore, cellular coordination between AA demand and nutrient availability seems indispensable.

Milk protein synthesis is regulated at the transcription level by the lactogenic hormones prolactin and glucocorticoids (Doppler et al., 1989). In early lactation, milk protein gene expression is upregulated (Lemay et al., 2007; Wickramasinghe et al., 2012). However, after initiation of lactation in mice, milk protein $\mathrm{mRNA}$ reach a steady state and regulation happens posttranscriptionally (Lemay et al., 2007). In agreement with these observations, the Akt (also known as protein kinase B) pathway that mediates insulin effects on mRNA translation is upregulated during lactation (Lemay et al., 2007).

Translation of milk protein mRNA is regulated via the activity of initiation and elongation factors. Nutrients and hormones activate signaling pathways that control the activity of these factors. The mTOR pathway is the pathway most studied with respect to nutritional regulation of translation. The mTORC1 complex regulates the rate of protein translation and cell growth through intermediates: eIF4E-binding protein 1 (4EBP1), ribosomal protein S6 kinase 1 (S6K1), and eukaryotic elongation factor 2 (eEF2, Figure 5; Sarbassov et al., 2004; Mahoney et al., 2009; Gan et al., 2011). In mammary tissue of lactating cows, phosphorylation of mTOR and 4EBP1 were positively correlated, whereas eEF2 phosphorylation was negatively correlated with casein synthesis rates (Appuhamy et al., 2011).

Insulin and IGF-1 are indicators of positive energy status, and as such, they stimulate anabolic processes in peripheral tissues in all vertebrates (Davis et al., 2002; Stump et al., 2003; Castillo et al., 2004). Insulin binding to its membrane receptor sequentially activates the Akt pathway (Bellacosa et al., 1998). In MAC-T cells, insulin stimulated phosphorylation of insulin receptor substrate 1 (IRS1), Akt, and downstream proteins (Appuhamy et al., 2011). Local energy status is also sensed intracellularly by the AMP-activated protein kinase (AMPK), which detects increases in the AMP:ATP ratio (Hardie, 2004). Activation of AKT and AMPK results in a cascade of kinase activities that are integrated by mTORC1. Signaling by mTORC1 also responds to EAA. Therefore, mTORC1 integrates endocrine and cellular nutrient signals to ensure proper matching of protein synthesis with local EAA and energy and systemic nutritional state availability.

Much progress has been made recently in understanding AA effects on mTORC1 activity. Essential AA, es- 


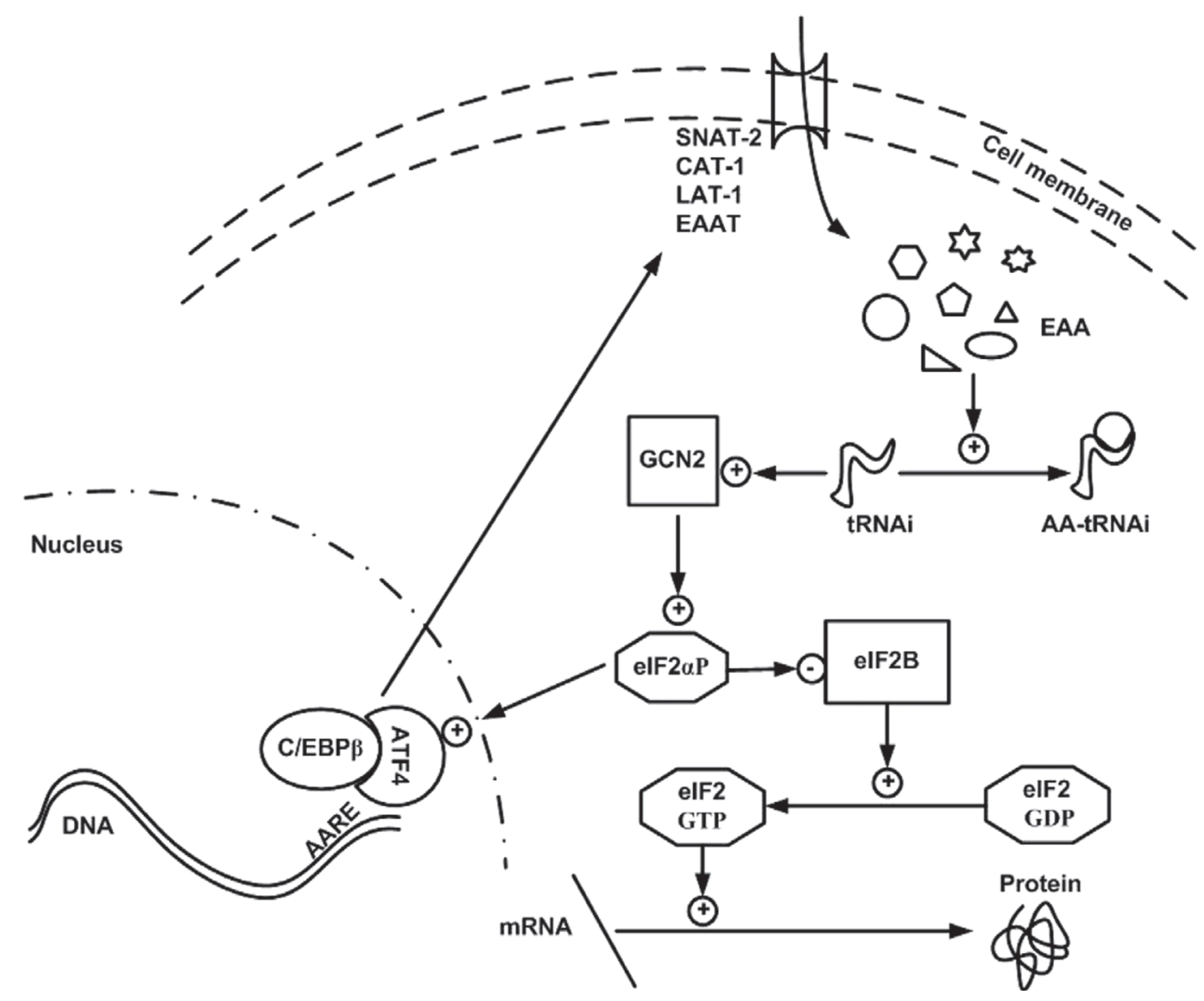

Figure 4. Schematic representation of the general AA response pathway involved in protein translation and AA transporter gene expression regulation in mammalian cells derived from Kilberg et al. (2005) and Kimball et al. (1989). ATF4 = activating transcription factor 4; C/EBP $\beta$ $=\mathrm{CCAAT}$ enhancer binding protein; eIF $2 \alpha \mathrm{P}=$ eukaryotic initiation factor $2 \alpha$ subunit phosphorylated in the Ser51 phospho site; eIF2B $=$ eukaryotic initiation factor 2B; GCN2 = general control non-derepressible 2; tRNAi = individual transfer RNA. Stimulatory effects are designated by + and inhibitory effects by - .

pecially Leu, activate mTORC1 through its recruitment to the lysosomal membrane (Sancak et al., 2010; Han et al., 2012). Appuhamy et al. (2012) observed effects of Ile as well as Leu on mTOR phosphorylation and casein fractional synthesis rates in mammary tissue. In agreement, Moshel et al. (2006) reported that mTOR signaling in mammary epithelial cells was more sensitive to all AA than to Leu alone, and this effect was reflected in synthesis rates of $\beta$-lactoglobulin. Essential AA effects on mTOR signaling did not show saturation over a wide range of concentrations beyond physiological levels (Arriola Apelo et al., 2014). Recently, it was reported that a Val-deficient diet limited milk protein synthesis in dairy cows (Haque et al., 2013). However, it is unknown whether the observed effects were due to Val as a substrate or via its cell signaling effects.

The integrated stress response pathway is also regulated by EAA (Figure 4). Four distinct kinases activate this pathway in response to different environmental signals (Wek et al., 2006). General control non-derepress- able 2 (GCN-2) senses AA depletion by binding with deacylated tRNA and subsequently phosphorylates eIF $2 \alpha$ (Wek et al., 1995). Phosphorylation of eIF $2 \alpha$ blocks the release of GDP upon hydrolysis from eIF2 and stops methionyl-tRNA recruitment to the 40S ribosomal subunit (Kimball et al., 1989). In MAC-T cells, His and BCAA supplementation reduce eIF $2 \alpha$ phosphorylation (Arriola Apelo et al., 2010). However, in mammary tissue slices, no effect of these AA on eIF $2 \alpha$ phosphorylation was observed despite changes in milk protein synthesis rates (Appuhamy et al., 2012).

By coordinating EAA and energy supply with demand for protein synthesis, mammary cells avoid the potentially costly mistake of synthesizing cell machinery when substrate supply is inadequate. This cellular strategy opens the possibility for nutritional manipulation by reducing dietary protein supply and supplementing with specific AA that activate the corresponding signaling pathways. This strategy would maximize mammary use of AA for protein synthesis 


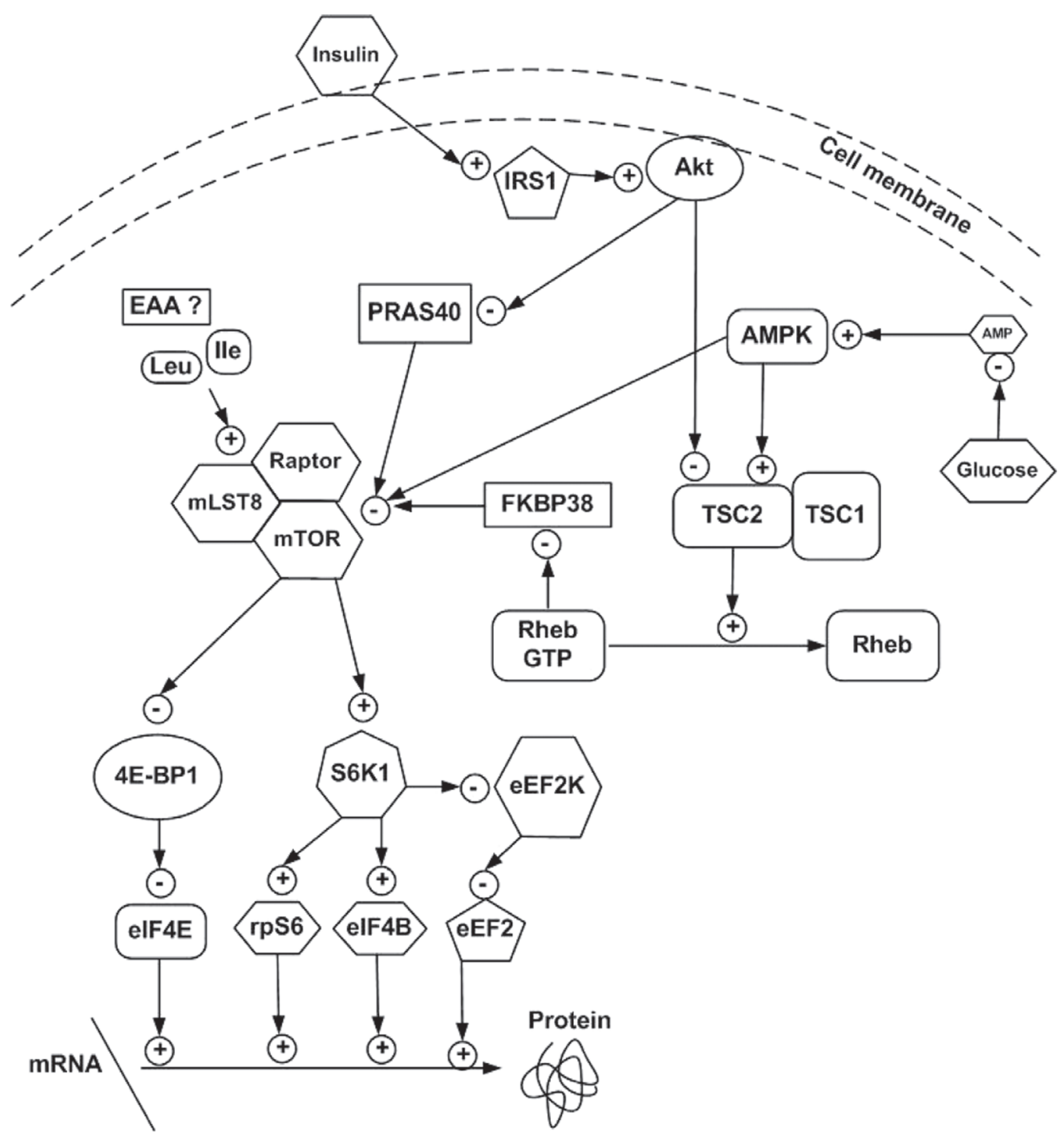

Figure 5. Mammalian target of rapamycin complex 1 (mTORC1) translation regulation pathway. Depicted are the effects of insulin, AMP, and identified AA, as well as other potential essential AA, on mTORC1 pathway. Several effects of the mTORC1 downstream protein on translation regulation are also represented (Bellacosa et al., 1998; Hardie, 2004; Mahoney et al., 2009). 4EBP1 = eukaryotic initiation factor 4 E binding protein 1; AMPK = AMP kinase; Akt = protein kinase B; eEF2 = eukaryotic elongation factor 2; eEF2K = eukaryotic elongation factor 2 kinase; eIF4E = eukaryotic initiation factor $4 \mathrm{E}$; FKBP38 = FK506 binding protein 38; IRS1 = insulin receptor substrate 1; mLST8 = mammalian lethal with SEC3 protein 8; PRAS40 = proline-rich Akt substrate $40 \mathrm{kDa}$; Rheb = Ras homolog enriched in brain; rpS6 = ribosomal protein S6; $\mathrm{TSC}=$ tuberous sclerosis complex; S6K1 = ribosomal protein S6 kinase 1. Stimulatory effects are designated by + and inhibitory effects by - .

and minimize AA recycling to splanchnic tissues, thus improving AA efficiency and reducing $\mathrm{N}$ excretion.

Several efforts to model nutrient metabolism at the tissue level have been undertaken (Hanigan et al., 2001, 2004a,b). Incorporation of cellular signaling regulation into those models seems to be the next logical step to reach the final objective of predicting tissue responses to nutrient availability and homeostatic and homeorhetic regulation. In turn, this understanding can be aggregated in nutritional models at the animal level to better represent nutrient utilization efficiency and reduce the environmental effect of the dairy industry. Initial attempts have resulted in a comprehensive model of the regulation of mRNA translation, which included predictions of signaling protein activation by EAA and insulin, and protein synthesis rates (El-Haroun et al., 2010). Parameter values were derived from the literature, but the model has not been validated with independent data. Other efforts include mechanistic models of translation that do not include nutritional regulation 
and lack applicability with respect to the objective of improving gross $\mathrm{N}$ efficiency (Basu and Chowdhury, 2007; Tuller et al., 2010; Sharma and Chowdhury, 2011).

Attempts have also been made to represent individual signaling pathways. A model of the mTOR pathway activation by AA and insulin was recently developed (Vinod and Venkatesh, 2009). The model predicted saturable responses in mTOR and S6K1 phosphorylation with respect to supply of AA and additive effects of insulin. Interestingly, it also includes a negative feedback of AA on the insulin pathway and glucose transporter GLUT4 translocation to the cytoplasmic membrane. Similar to protein synthesis models presented above, this model requires specific inputs that limit its use in nutritional research. Appuhamy and Hanigan (2010) represented the mTOR pathway activation in a simplified representation with 3 proteins (Akt, mTOR, and 4EBP1) and 6 pools (phosphorylated and unphosphorylated for each protein). Phosphorylation was driven by mass action as a function of insulin and EAA concentrations (Figure $6)$. Phosphorylation of downstream proteins (mTOR and 4EBP1) was predicted with minimal error $(<10 \%)$. As additional data are generated, this model could be incorporated into existing tissue models and evaluated for accuracy of prediction. However, this level of complexity should not be required nor would it be desirable for incorporation into animal requirement models for production purposes. Rather, these molecular and cellular models identify sources of variation in response variables and provide a quantitative understanding of the importance of these mechanisms with respect to deficiencies in existing requirement systems. Through such understanding, we can gain the knowledge required to construct more aggregated and empirical representations of the key elements for use in our requirement systems.

\section{Mammary Blood Flow}

Several studies have investigated local effects of nutrients on mammary blood flow. Increasing levels of Lys up to $63 \mathrm{~g} / \mathrm{d}$ increased arterial Lys but had no effect on blood flow (Guinard and Rulquin, 1994). Guinard and Rulquin (1995) used an addition approach to investigate the effect of Met on mammary blood flow in mid-lactation Holstein cows (84 to 154 DIM) consuming a $17.8 \% \mathrm{CP}$ diet and producing $24 \mathrm{~kg} / \mathrm{d}$ of milk. Duodenal infusion of $16 \mathrm{~g}$ of Met significantly reduced blood flow compared with the basal diet, but that effect disappeared when the Met dose was doubled. Bequette et al. $(1996,2000)$ observed 17 and $36 \%$ increases in mammary blood flow when EAA mixtures depleted of Leu or His, respectively, were infused into lactating goats. In contrast, in dairy cows fed a $16 \% \mathrm{CP}$ diet, a 10-h unilateral infusion of $30 \mathrm{~g} / \mathrm{h}$ of an AA mixture with or without His at the external iliac artery did not affect mammary blood flow (Cant et al., 2001). In Holstein cows fed $13.9 \%$ CP diets (72\% MP requirement) and producing $34.5 \mathrm{~kg} / \mathrm{d}$ of milk, abomasal infusion of all the EAA $(359 \mathrm{~g} / \mathrm{d})$ reduced blood flow to the MG by $10 \%$ compared with treatments that did not receive EAA, whereas infusion of NEAA (356 g/d) tended to increase (7\%) blood flow (Doepel and Lapierre, 2010). Similarly, duodenal infusion of casein $(743 \mathrm{~g} / \mathrm{d})$ reduced mammary blood flow by 17\% (Lemosquet et al., 2009). The same effect was not observed when $860 \mathrm{~g} / \mathrm{d}$ of casein was infused abomasally (Rius et al., 2010) or when dietary RUP supply was increased (Metcalf et al., 1996b). In a meta-analysis considering 52 treatments from 24 experiments, a poor negative relationship between MP supply and mammary blood flow was observed (Lapierre et al., 2012). In lactating rats, $18 \mathrm{~h}$ of total feed deprivation reduced mammary blood flow $50 \%$ (Stewart et al., 2009). Refed rats recovered mammary blood flow to initial levels within $60 \mathrm{~min}$. In this latter work, dietary energy was a confounding effect.

Provision of glucose to Holstein cows (81 DIM) producing $32 \mathrm{~kg} / \mathrm{d}$ of milk increased mammary blood flow linearly, affecting the net removal of EAA (Rulquin et al., 2004). Propionate infusion increased arterial glucose and mammary blood flow followed a very similar pattern (Lemosquet et al., 2009). Rius et al. (2010)

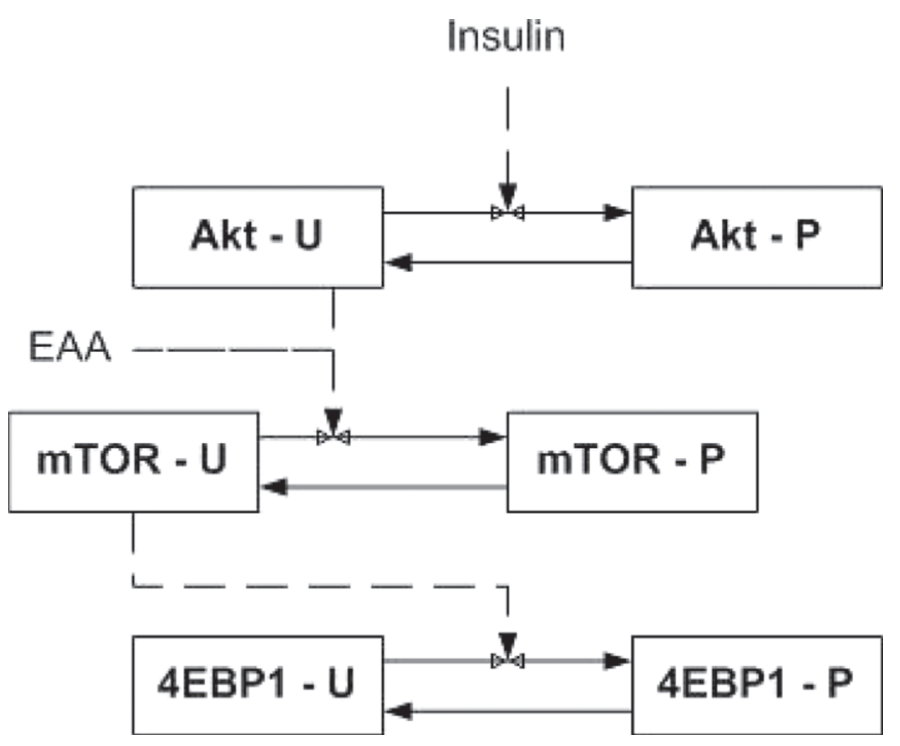

Figure 6. Schematic of the mTORC1 signaling pathway model derived from Appuhamy and Hanigan (2010). Solid arrows represent fluxes, dashed arrows represent regulatory effects on the fluxes, and solid boxes represent protein pools. $4 \mathrm{EBP} 1=$ eukaryotic initiation factor $4 \mathrm{E}$ binding protein 1 ; Akt $=$ protein kinase $\mathrm{B}$; $\mathrm{mTORC} 1=$ mammalian target of rapamycin complex 1; $\mathrm{U}=$ unphosphorylated; $\mathrm{P}$ $=$ phosphorylated. 
observed an increase in mammary blood flow and nitric oxide synthase phosphorylation (indicating enzyme activity) in response to abomasal infusion of starch (2 $\mathrm{kg} / \mathrm{d}$ ) to Holstein cows (160 DIM) producing $40 \mathrm{~kg} / \mathrm{d}$ of milk. The mechanism behind nitric oxide synthase activation is unclear, because no effect on Akt phosphorylation, a key intermediate in the insulin signaling pathway, was observed (Rius et al., 2010). On the other hand, Bequette et al. (2001) reported a $42 \%$ increase in mammary blood flow of lactating goats during a hyperinsulinemic-euglycemic clamp, suggesting that glucose responses are indirectly mediated by insulin. A common factor between the Rius et al. (2010) and Bequette et al. (2001) study is the increase in plasma IGF1 concentration. From these observations, it appears that the MG regulates local blood flow in response to nutrient deficiency or imbalance, thus affecting nutrient partitioning.

Blood flow has been described as a linear function of milk yield (Kronfeld et al., 1968; Hanigan et al., 2002). Cant and McBride (1995) represented mammary blood flow as a negative function of intracellular ATP:ADP ratio. Based on that model, increasing blood nutrient concentrations (AA, acetate, and glucose) would reduce blood flow due to an increase in the ATP:ADP ratio. Conversely, reducing nutrient concentrations increased blood flow and clearance per unit of time of AA, fatty acids, and glucose, but not acetate by the MG. That effect has been experimentally observed for infusions of EAA (Doepel and Lapierre, 2010), but not for NEAA, total AA (Metcalf et al., 1996a), or glucose (Rulquin et al., 2004). A more comprehensive representation of local blood flow regulation in the MG has not been published. Further research is needed to understand the mechanisms controlling blood flow regulation in the MG and other tissues if we are to achieve a better description of variable partial efficiencies in postabsorptive $\mathrm{N}$ metabolism. We expect that local blood flow regulation is a nonlinear function of at least several independent nutrients such as glucose and individual EAA. However, data availability does not currently allow parameterization of such a representation.

\section{NUTRIENT INTERACTIONS}

The single limiting AA theory applied to animal nutrition is based on the Law of the Minimum that derives from the work by the German botanist Carl Sprengel in 1828. The original hypothesis stated that a nutrient can limit plant growth and, when limiting, growth will be proportional to supply. von Liebig (1863) subsequently restated the hypothesis in stronger terms, indicating that if a nutrient was limiting for growth, responses to other nutrients could not occur. Mitchell and Block
(1946) used von Liebig's extension of Sprengel's hypothesis to develop the concept of the order of limiting AA, which is commonly described using the analogy of a water barrel with broken staves, where only the AA represented by the shortest stave can cause a response (Cant et al., 2003). Based on this concept, if an AA is limiting milk production, then only the addition of that AA to the diet will result in a positive milk yield response; for example, the single-limiting AA theory. Several studies at the animal level have challenged this theory, whereas others agree with it (reviewed in Cant et al., 2003). Hanigan et al. (2000) observed that the effects of individual AA on milk protein synthesis were better represented by consideration of multiple AA as independent and additive effectors of protein synthesis using a Michaelis-Menten model than the single-limiting AA approach.

Milk protein synthesis is a multi-step enzymatic process that happens in the cell at a rate determined by substrate availability and enzyme catalytic potential. Essential AA can affect milk protein synthesis by activating signaling proteins that modify enzyme catalytic potential, or when in short supply via a reduction in tRNA loading and thus substrate availability. It was previously assumed that tRNA loading was not limiting for protein synthesis (Cant et al., 2003). However, there have been observed responses in milk protein synthesis to EAA without activation of signaling pathways (Appuhamy et al., 2012). Elf et al. (2003) demonstrated that when an AA becomes limiting, the charging level of some iso-acceptor tRNA can approach zero, whereas others remain fully loaded. The rate of translation of the respective codons could thus differ greatly due to substrate availability. This study also showed that iso-acceptor sensitivity to AA deficiency and codon usage (frequency of appearance in genes expressed in the cell) were not necessarily correlated. The concept of differential iso-acceptor loading validates the multisubstrate application of the Michaelis-Menten equation for protein synthesis (Hanigan et al., 2000). It also agrees with early studies where addition of individual EAA (Clark et al., 1978) or groups of AA (Park et al., 1976) to mammary explants independently increased the rate of milk protein synthesis. Recently, Appuhamy et al. (2012) observed no effects of Met and Thr on signaling proteins in mammary tissue slices, but these AA did affect casein synthesis rate, suggesting either a substrate affect or an unknown signaling mechanism. We recently studied the effect of Ile, Leu, Met, and Thr on fractional synthesis rates of casein using mammary tissue slices from lactating cows and observed additive (nonsignificant interactions) and saturable effects of the $4 \mathrm{AA}$, contradicting the single limiting AA theory (Arriola Apelo et al., 2014). 
As previously discussed, signaling pathways that regulate translation initiation and elongation have been shown to respond to specific EAA. In mammary tissue slices, Leu, Ile, and Thr have been shown to activate the mTOR pathway (Appuhamy et al., 2012; Arriola Apelo et al., 2014). Increasing the maximum catalytic rate $\left(V_{\max }\right)$ in the absence of a change in substrate affinity $\left(k_{m}\right)$ at a given concentration of substrate will result in increased catalytic rates (mRNA translation). Therefore, Leu or Ile could independently and additively stimulate protein synthesis even when they are not considered first limiting according to the hypothesis. This contradicts the single-limiting AA theory because the cell may respond to not only Leu and Ile, but perhaps also to other AA (e.g., Met or Thr) that are altering translation rates due to substrate availability (Arriola Apelo et al., 2014). Moreover, mTOR can also be regulated by hormonal or intracellular energy signals, thereby either causing an increase in protein synthesis when it is activated in the absence of a change in the limiting AA or decreasing synthesis when not activated even if more of the limiting AA is provided.

Postruminal infusion of casein and glucose produced an additive response in MPY in lactating cows (Vanhatalo et al., 2003). This response can be partially explained by an increase in arterial concentrations of some EAA due to reduced hepatic use (Vanhatalo et al., 2003). However, Rius et al. (2010) determined that part of the response to increased postruminal glucose (via starch) supply was explained by changes in phosphorylation state of the mTOR pathway proteins in mammary tissue in response to increased concentrations of blood glucose. In MAC-T cells, EAA and insulin additively activated the mTOR pathway (Appuhamy et al., 2011). Furthermore, in MAC-T cells and mammary tissue slices, individual EAA independently affected the phosphorylation state of mTOR (Appuhamy et al., 2012). These changes were correlated with changes in rates of casein synthesis in mammary tissue slices.

The evidence conclusively indicates that EAA availabilities, energy supply, and hormone concentrations all independently stimulate rates of milk protein synthesis through the activation of signaling pathways, contradicting the single limiting nutrient theory at the tissue level. Thus, additive nutrient effects, in addition to variable partial AA efficiencies, should be included in nutrient requirement models to better represent responses to EAA and energy, and in this way improve $\mathrm{N}$ utilization and reduce $\mathrm{N}$ excretion.

\section{CONCLUSIONS}

Current understanding of EAA metabolism is adequate to allow improvement of nutrient requirement systems for dairy cattle that should reduce prediction errors and increase the robustness of the system through the incorporation of metabolic mechanisms as a pillar for future contributions. An improved representation of the biology of milk protein synthetic processes should include (1) individual EAA rather than the aggregated representation as MP, (2) variable partial efficiencies of AA utilization, and (3) the effects of multiple nutrients on AA utilization. Variable efficiencies reflect the saturable nature of enzymatic reactions in protein synthesis and are a function, in part, of local regulation of nutrient utilization. Among those mechanisms, local regulation of blood flow has been demonstrated to interact with tissue affinities and determine nutrient uptake. Progress in understanding the regulation of AA transport in mammary cells is encouraging, but quantifying the systems that transport each of the EAA at a molecular level, the overlap between them, and the mechanisms regulating them remains to be completed. However, it is clear from infusion studies that AA transport systems can respond to changes in AA supply and at least partially mitigate supply shortages. Amino acid transport systems are also coordinated with intracellular signaling pathways so that AA availability and tissue demand for protein synthesis are matched. The progress obtained in understanding signaling pathways, their mechanisms of activation, and their effects on translation regulation has been remarkable. Furthermore, understanding these pathways has led to the concept that individual EAA and energy can independently stimulate protein synthesis at the cellular level, in agreement with observations at the animal level. Such concepts are inconsistent with the single limiting AA and the single limiting nutrient theory. Differential responses to individual EAA limit the use of an aggregated representation of AA requirements as MP. This approach fails to capture milk protein responses to corrections in dietary EAA profile without changing total $\mathrm{N}$ supply. The aggregated representation of AA as MP also fails to capture variable utilization efficiencies between tissues, especially splanchnic and MG, which modify EAA availability for cellular processes. Requirements are overestimated because protein must be supplied at a level to meet the needs of those EAA used with the least efficiency relative to supply. Incorporation of these concepts into future requirement systems should allow formulation of rations with lower CP levels in concert with selected supplementation of specific EAA. This approach should increase postabsorptive partial efficiencies and reduce $\mathrm{N}$ excretion to the environment, thus improving dairy industry economics and reducing environmental impact. 


\section{ACKNOWLEDGMENTS}

This project was supported in part by Agriculture and Food Research Initiative Competitive Grant no. 201267015-19464 from the USDA National Institute of Food and Agriculture (Washington, DC). S. I. Arriola Apelo received fellowship support from the John Lee Pratt Foundation (Virginia Tech, Blacksburg).

\section{REFERENCES}

AFRC (Agriculture and Food Research Council). 1992. Technical Committee on Responses to Nutrients. Report No. 9. Nutritive Requirements of Ruminant Animals: Energy. Nutr. Abstr. Rev. B 62:787-835.

Akers, R. M. 2002. Lactation and the Mammary Gland. 1st ed. Iowa State Press, Ames.

Anthony, T. G., B. J. McDaniel, R. L. Byerley, B. C. McGrath, D. R. Cavener, M. A. McNurlan, and R. C. Wek. 2004. Preservation of liver protein synthesis during dietary leucine deprivation occurs at the expense of skeletal muscle mass in mice deleted for eIF2 kinase GCN2. J. Biol. Chem. 279:36553-36561.

Appuhamy, J. A. D. R. N., A. L. Bell, W. A. D. Nayananjalie, J. Escobar, and M. D. Hanigan. 2011. Essential amino acids regulate both initiation and elongation of mRNA translation independent of insulin in MAC-T cells and bovine mammary tissue slices. J. Nutr. 141:1209-1215.

Appuhamy, J. A. D. R. N., and M. D. Hanigan. 2010. Modeling the effects of insulin and amino acids on the phosphorylation of mTOR, Akt and 4EBP1 in mammary cells. Pages 225-232 in Modelling Nutrient Digestion and Utilisation in Farm Animals. D. Sauvant, J. V. Milgen, P. Faverdin, and N. Friggens, ed. Wageningen Academic Publishers, Wageningen, the Netherlands.

Appuhamy, J. A. D. R. N., N. A. Knoebel, W. A. D. Nayananjalie, J. Escobar, and M. D. Hanigan. 2012. Isoleucine and leucine independently regulate mTOR signaling and protein synthesis in MAC-T cells and bovine mammary tissue slices. J. Nutr. 142:484-491.

Arriola Apelo, S. I., W. A. D. Nayananjalie, J. A. D. R. N. Appuhamy, and M. D. Hanigan. 2010. mTOR independent model of protein synthesis regulation by essential amino acids in mammary epithelial cells. Page 247 in Energy and Protein Metabolism and Nutrition. M. G. Crovetto, ed. Wageningen Academic Publishers, Wageningen, the Netherlands.

Arriola Apelo, S. I., L. M. Singer, X. Y. Lin, M. L. McGilliard, N R. St-Pierre, and M. D. Hanigan. 2014. Isoleucine, leucine, methionine, and threonine effects on mammalian target of rapamycin signaling in mammary tissue. J. Dairy Sci. 97:1047-1056.

Arriola Apelo, S. I., L. M. Singer, W. K. Ray, R. F. Helm, X. Y. Lin, M. L. McGilliard, N. R. St-Pierre, and M. D. Hanigan. 2014. Casein synthesis is independently and additively related to individual essential amino acid supply. J. Dairy Sci. 97:2998-3005.

Baker, D. H. 1996. Advances in amino acid nutrition and metabolism of swine and poultry. Pages 41-52 in Nutrient Management of Food Animals to Enhance and Protect the Environment. E. T. Kornegay, ed. CRC Lewis, Boca Raton, FL.

Basu, A., and D. Chowdhury. 2007. Modeling protein synthesis from a physicist's perspective: A toy model. Am. J. Phys. 75:931-937.

Baumrucker, C. R. 1985. Amino acid transport systems in bovine mammary tissue. J. Dairy Sci. 68:2436-2451.

Bellacosa, A., T. O. Chan, N. N. Ahmed, K. Datta, S. Malstrom, D. Stokoe, F. McCormick, J. Feng, and P. Tsichlis. 1998. Akt activation by growth factors is a multiple-step process: The role of the PH domain. Oncogene 17:313-325.

Bequette, B. J., F. R. C. Backwell, J. C. MacRae, G. E. Lobley, L. A Crompton, J. A. Metcalf, and J. D. Sutton. 1996. Effect of intravenous amino acid infusion on leucine oxidation across the mammary gland of the lactating goat. J. Dairy Sci. 79:2217-2224.
Bequette, B. J., M. D. Hanigan, A. G. Calder, C. K. Reynolds, G. E. Lobley, and J. C. MacRae. 2000. Amino acid exchange by the mammary gland of lactating goats when histidine limits milk production. J. Dairy Sci. 83:765-775.

Bequette, B. J., C. E. Kyle, L. A. Crompton, V. Buchan, and M. D. Hanigan. 2001. Insulin regulates milk production and mammary gland and hind-leg amino acid fluxes and blood flow in lactating goats. J. Dairy Sci. 84:241-255.

Blouin, J. P., J. F. Bernier, C. K. Reynolds, G. E. Lobley, P. Dubreuil, and H. Lapierre. 2002. Effect of supply of metabolizable protein on splanchnic fluxes of nutrients and hormones in lactating dairy cows. J. Dairy Sci. 85:2618-2630.

Cant, J. P., R. Berthiaume, H. Lapierre, P. H. Luimes, B. W. McBride, and D. Pacheco. 2003. Responses of the bovine mammary glands to absorptive supply of single amino acids. Can. J. Anim. Sci. $83: 341-355$.

Cant, J. P., and B. W. McBride. 1995. Mathematical analysis of the relationship between blood flow and uptake of nutrients in the mammary glands of a lactating cow. J. Dairy Res. 62:405-422.

Cant, J. P., D. R. Trout, F. Qiao, and B. W. McBride. 2001. Milk composition responses to unilateral arterial infusion of complete and histidine-lacking amino acid mixtures to the mammary glands of cows. J. Dairy Sci. 84:1192-1200.

Caraviello, D. Z., K. A. Weigel, P. M. Fricke, M. C. Wiltbank, M. J. Florent, N. B. Cook, K. V. Nordlund, N. R. Zwald, and C. L. Rawson. 2006. Survey of management practices on reproductive performance of dairy cattle on large US commercial farms. J. Dairy Sci. 89:4723-4735.

Castillo, J., M. Codina, M. L. Martínez, I. Navarro, and J. Gutiérrez. 2004. Metabolic and mitogenic effects of IGF-I and insulin on muscle cells of rainbow trout. Am. J. Physiol. Regul. Integr. Comp. Physiol. 286:R935-R941.

Clark, R. M., P. T. Chandler, and C. S. Park. 1978. Limiting amino acids for milk protein synthesis by bovine mammary cells in culture. J. Dairy Sci. 61:408-413.

Clark, R. M., P. T. Chandler, C. S. Park, and A. W. Norman. 1980. Extracellular amino acid effects on milk and intracellular amino acid pools with bovine mammary cells in culture. J. Dairy Sci. 63:1230-1234.

Cyriac, J., A. G. Rius, M. L. McGilliard, R. E. Pearson, B. J. Bequette, and M. D. Hanigan. 2008. Lactation performance of midlactation dairy cows fed ruminally degradable protein at concentrations lower than National Research Council recommendations. J. Dairy Sci. 91:4704-4713.

Davis, T. A., M. L. Fiorotto, D. G. Burrin, P. J. Reeds, H. V. Nguyen, P. R. Beckett, R. C. Vann, and P. M. J. O'Connor. 2002. Stimulation of protein synthesis by both insulin and amino acids is unique to skeletal muscle in neonatal pigs. Am. J. Physiol. Endocrinol. Metab. 282:E880-E890.

Delgado-Elorduy, A., C. B. Theurer, J. T. Huber, A. Alio, O. Lozano, M. Sadik, P. Cuneo, H. D. De Young, I. J. Simas, J. E. P. Santos, L. Nussio, C. Nussio, K. E. Webb Jr., and H. Tagari. 2002. Splanchnic and mammary nitrogen metabolism by dairy cows fed dry-rolled or steam-flaked sorghum grain. J. Dairy Sci. 85:148159.

Dijkstra, J., C. K. Reynolds, E. Kebreab, A. Bannink, J. L. Ellis, J. France, and A. M. van Vuuren. 2013. Challenges in ruminant nutrition: Towards minimal nitrogen losses in cattle. Pages 47-58 in Energy and Protein Metabolism and Nutrition in Sustainable Animal Production. W. J. Oltjen, E. Kebreab, and H. Lapierre, ed. Wageningen Academic Publishers, Wageningen, the Netherlands.

Doepel, L., and H. Lapierre. 2010. Changes in production and mammary metabolism of dairy cows in response to essential and nonessential amino acid infusions. J. Dairy Sci. 93:3264-3274.

Doepel, L., G. E. Lobley, J. F. Bernier, P. Dubreuil, and H. Lapierre. 2007. Effect of glutamine supplementation on splanchnic metabolism in lactating dairy cows. J. Dairy Sci. 90:4325-4333.

Doepel, L., D. Pacheco, J. J. Kennelly, M. D. Hanigan, I. F. López, and H. Lapierre. 2004. Milk protein synthesis as a function of amino acid supply. J. Dairy Sci. 87:1279-1297. 
Doppler, W., B. Groner, and R. K. Ball. 1989. Prolactin and glucocorticoid hormones synergistically induce expression of transfected rat $\beta$-casein gene promoter constructs in a mammary epithelial cell line. Proc. Natl. Acad. Sci. USA 86:104-108.

Drummond, M. J., E. L. Glynn, C. S. Fry, K. L. Timmerman, E. Volpi, and B. B. Rasmussen. 2010. An increase in essential amino acid availability upregulates amino acid transporter expression in human skeletal muscle. Am. J. Physiol. Endocrinol. Metab. 298:E1011-E1018.

El-Haroun, E. R., D. P. Bureau, and J. P. Cant. 2010. A mechanistic model of nutritional control of protein synthesis in animal tissues. J. Theor. Biol. 262:361-369.

El-Kadi, S. W., R. L. Baldwin, N. E. Sunny, S. L. Owens, and B. J. Bequette. 2006. Intestinal protein supply alters amino acid, but not glucose, metabolism by the sheep gastrointestinal tract. J. Nutr. 136:1261-1269.

Elf, J., D. Nilsson, T. Tenson, and M. n. Ehrenberg. 2003. Selective charging of tRNA isoacceptors explains patterns of codon usage. Science 300:1718-1722.

Farr, V. C., C. G. Prosser, and S. R. Davis. 2000. Effects of mammary engorgement and feed withdrawal on microvascular function in lactating goat mammary glands. Am. J. Physiol. Heart Circ. Physiol. 279:H1813-H1818.

Gan, X., J. Wang, B. Su, and D. Wu. 2011. Evidence for direct activation of mTORC2 kinase activity by phosphatidylinositol 3,4,5-trisphosphate. J. Biol. Chem. 286:10998-11002.

Guinard, J., and H. Rulquin. 1994. Effects of graded amounts of duodenal infusions of lysine on the mammary uptake of major milk precursors in dairy cows. J. Dairy Sci. 77:3565-3576.

Guinard, J., and H. Rulquin. 1995. Effects of graded amounts of duodenal infusions of methionine on the mammary uptake of major milk precursors in dairy cows. J. Dairy Sci. 78:2196-2207.

Han, J. M., S. J. Jeong, M. C. Park, G. Kim, N. H. Kwon, H. K. Kim, S. H. Ha, S. H. Ryu, and S. Kim. 2012. Leucyl-tRNA synthetase is an intracellular leucine sensor for the mTORC1-signaling pathway. Cell 149:410-424.

Hanigan, M. D. 2005. Quantitative aspects of ruminant splanchnic metabolism as related to predicting animal performance. Anim. Sci. 80:23-32.

Hanigan, M. D., C. C. Calvert, E. J. DePeters, B. L. Reis, and R. L. Baldwin. 1992. Kinetics of amino acid extraction by lactating mammary glands in control and sometribove-treated Holstein cows. J. Dairy Sci. 75:161-173.

Hanigan, M. D., J. P. Cant, D. C. Weakley, and J. L. Beckett. 1998a. An evaluation of postabsorptive protein and amino acid metabolism in the lactating dairy cow. J. Dairy Sci. 81:3385-3401.

Hanigan, M. D., L. A. Crompton, B. J. Bequette, J. A. Mills, and J. France. 2002. Modelling mammary metabolism in the dairy cow to predict milk constituent yield, with emphasis on amino acid metabolism and milk protein production: Model evaluation. J. Theor. Biol. 217:311-330.

Hanigan, M. D., L. A. Crompton, J. A. Metcalf, and J. France. 2001. Modelling mammary metabolism in the dairy cow to predict milk constituent yield, with emphasis on amino acid metabolism and milk protein production: Model construction. J. Theor. Biol. 213:223-239.

Hanigan, M. D., L. A. Crompton, C. K. Reynolds, D. Wray-Cahen, M. A. Lomax, and J. France. 2004a. An integrative model of amino acid metabolism in the liver of the lactating dairy cow. J. Theor. Biol. 228:271-289.

Hanigan, M. D., J. France, L. A. Crompton, and B. J. Bequette. 2000. Evaluation of a representation of the limiting amino acid theory for milk protein synthesis. Pages 225-232 in Modelling Nutrient Utilization in Farm Animals. J. P. McNamara, J. France, and D. E. Beever, ed. CABI, Wallingford, UK.

Hanigan, M. D., J. France, D. Wray-Cahen, D. E. Beever, G. E. Lobley, L. Reutzel, and N. E. Smith. 1998b. Alternative models for analyses of liver and mammary transorgan metabolite extraction data. Br. J. Nutr. 79:63-78.

Hanigan, M. D., C. K. Reynolds, D. J. Humphries, B. Lupoli, and J. D. Sutton. 2004b. A model of net amino acid absorption and utili- zation by the portal-drained viscera of the lactating dairy cow. J. Dairy Sci. 87:4247-4268.

Haque, M. N., H. Rulquin, A. Andrade, P. Faverdin, J. L. Peyraud, and S. Lemosquet. 2012. Milk protein synthesis in response to the provision of an "ideal" amino acid profile at 2 levels of metabolizable protein supply in dairy cows. J. Dairy Sci. 95:5876-5887.

Haque, M. N., H. Rulquin, and S. Lemosquet. 2013. Milk protein responses in dairy cows to changes in postruminal supplies of arginine, isoleucine, and valine. J. Dairy Sci. 96:420-430.

Hardie, D. G. 2004. The AMP-activated protein kinase pathway-New players upstream and downstream. J. Cell Sci. 117:5479-5487.

Hristov, A. N., R. P. Etter, J. K. Ropp, and K. L. Grandeen. 2004a. Effect of dietary crude protein level and degradability on ruminal fermentation and nitrogen utilization in lactating dairy cows. J. Anim. Sci. 82:3219-3229.

Hristov, A. N., W. J. Price, and B. Shafii. 2004b. A meta-analysis examining the relationship among dietary factors, dry matter intake, and milk and milk protein yield in dairy cows. J. Dairy Sci. $87: 2184-2196$.

Kilberg, M. S., Y.-X. Pan, H. Chen, and V. Leung-Pineda. 2005. Nutritional control of gene expression: How mammalian cells respond to amino acid limitation. Annu. Rev. Nutr. 25:59-85.

Kimball, S. R., W. V. Everson, K. E. Flaim, and L. S. Jefferson. 1989. Initiation of protein synthesis in a cell-free system prepared from rat hepatocytes. Am. J. Physiol. 256:C28-C34.

Kronfeld, D. S., F. Raggi, and C. Ramberg. 1968. Mammary blood flow and ketone body metabolism in normal, fasted and ketotic cows. Am. J. Physiol. 215:218-227.

Lapierre, H., R. Berthiaume, G. Raggio, M. C. Thivierge, L. Doepel, D. Pacheco, P. Dubreuil, and G. E. Lobley. 2005. The route of absorbed nitrogen into milk protein. Anim. Sci. 80:11-22.

Lapierre, H., C. E. Galindo, S. Lemosquet, I. Ortigues-Marty, L. Doepel, and D. R. Ouellet. 2010. Protein supply, glucose kinetics and milk yield in dairy cows. Pages 275-286 in Energy and Protein Metabolism and Nutrition. G. M. Crovetto, ed. Wageningen Academic Publishers, Wageningen, the Netherlands.

Lapierre, H., and G. E. Lobley. 2001. Nitrogen recycling in the ruminant: A review. J. Dairy Sci. 84(E-Suppl.):E223-E236.

Lapierre, H., G. E. Lobley, L. Doepel, G. Raggio, H. Rulquin, and S. Lemosquet. 2012. Triennial Lactation Symposium: Mammary metabolism of amino acids in dairy cows. J. Anim. Sci. 90:17081721.

Lapierre, H., D. R. Ouellet, R. Berthiaume, R. Martineau, G. Holtrop, and G. E. Lobley. 2008. Distribution of ${ }^{15} \mathrm{~N}$ in amino acids during ${ }^{15} \mathrm{~N}$-leucine infusion: Impact on the estimation of endogenous flows in dairy cows. J. Dairy Sci. 91:2702-2714.

Larsen, M., and N. B. Kristensen. 2009. Effect of abomasal glucose infusion on splanchnic amino acid metabolism in periparturient dairy cows. J. Dairy Sci. 92:3306-3318.

Lemay, D. G., M. Neville, M. Rudolph, K. Pollard, and J. German. 2007. Gene regulatory networks in lactation: Identification of global principles using bioinformatics. BMC Syst. Biol. 1:56.

Lemosquet, S., G. Raggio, G. E. Lobley, H. Rulquin, J. Guinard-Flament, and H. Lapierre. 2009. Whole-body glucose metabolism and mammary energetic nutrient metabolism in lactating dairy cows receiving digestive infusions of casein and propionic acid. J. Dairy Sci. 92:6068-6082.

Lobley, G. E., D. M. Bremner, and G. Zuur. 2000a. Effects of diet quality on urea fates in sheep as assessed by refined, non-invasive $\left[{ }^{15} \mathrm{~N}^{15} \mathrm{~N}\right]$ urea kinetics. Br. J. Nutr. 84:459-468.

Lobley, G. E., G. D. Milano, and J. G. van der Walt. 2000b. The liver: Integrator of nitrogen metabolism. Pages 149-168 in Ruminant Physiology: Digestion, Metabolism, Growth, and Reproduction. P. B. Cronjé, ed. CABI Publishing, New York, NY.

Lobley, G. E., X. Shen, G. Le, D. M. Bremner, E. Milne, A. G. Calder, S. E. Anderson, and N. Dennison. 2003. Oxidation of essential amino acids by the ovine gastrointestinal tract. Br. J. Nutr. $89: 617-630$

Lomax, M. A., and G. D. Baird. 1983. Blood flow and nutrient exchange across the liver and gut of the dairy cow. Br. J. Nutr. 49:481-496. 
Mackenzie, B., and J. Erickson. 2004. Sodium-coupled neutral amino acid (system N/A) transporters of the SLC38 gene family. Pflugers Arch. 447:784-795.

Mackle, T. R., D. A. Dwyer, K. L. Ingvartsen, P. Y. Chouinard, D. A. Ross, and D. E. Bauman. 2000. Effects of insulin and postruminal supply of protein on use of amino acids by the mammary gland for milk protein synthesis. J. Dairy Sci. 83:93-105.

MacRae, J. C., L. A. Bruce, D. S. Brown, and A. G. Calder. 1997a. Amino acid use by the gastrointestinal tract of sheep given lucerne forage. Am. J. Physiol. 273:G1200-G1207.

MacRae, J. C., L. A. Bruce, D. S. Brown, D. A. Farningham, and M. Franklin. 1997b. Absorption of amino acids from the intestine and their net flux across the mesenteric- and portal-drained viscera of lambs. J. Anim. Sci. 75:3307-3314.

Mahoney, S. J., J. M. Dempsey, and J. Blenis. 2009. Cell signaling in protein synthesis: Ribosome biogenesis and translation initiation and elongation. Pages 53-107 in Prog. Mol. Biol. Transl. Sci. Vol. 90. W. B. H. John, ed. Academic Press, San Diego, CA.

Marini, J. C., and M. E. Van Amburgh. 2003. Nitrogen metabolism and recycling in holstein heifers. J. Anim. Sci. 81:545-552.

Menzies, K. K., C. Lefèvre, K. Macmillan, and K. Nicholas. 2009. Insulin regulates milk protein synthesis at multiple levels in the bovine mammary gland. Funct. Integr. Genomics 9:197-217.

Metcalf, J. A., L. A. Crompton, D. Wray-Cahen, M. A. Lomax, J. D. Sutton, D. E. Beever, J. C. MacRae, B. J. Bequette, F. R. C. Backwell, and G. E. Lobley. 1996a. Responses in milk constituents to intravascular administration of two mixtures of amino acids to dairy cows. J. Dairy Sci. 79:1425-1429.

Metcalf, J. A., R. J. Mansbridge, J. S. Blake, J. D. Oldham, and J. R. Newbold. 2008. The efficiency of conversion of metabolisable protein into milk true protein over a range of metabolisable protein intakes. Animal 2:1193-1202.

Metcalf, J. A., D. Wray-Cahen, E. E. Chettle, J. D. Sutton, D. E. Beever, L. A. Crompton, J. C. Macrae, B. J. Bequette, and F. R. C. Backwell. 1996b. The effect of dietary crude protein as protected soybean meal on mammary metabolism in the lactating dairy cow. J. Dairy Sci. 79:603-611.

Mitchell, H. H., and R. J. Block. 1946. Some relationships between the amino acid contents of proteins and their nutritive values for the rat. J. Biol. Chem. 163:599-620.

Moshel, Y., R. E. Rhoads, and I. Barash. 2006. Role of amino acids in translational mechanisms governing milk protein synthesis in murine and ruminant mammary epithelial cells. J. Cell. Biochem. 98:685-700.

Nahm, K. H. 2002. Efficient feed nutrient utilization to reduce pollutants in poultry and swine manure. Crit. Rev. Environ. Sci. Technol. 32:1-16.

NASS. 2013. National statistics for soybeans. Accessed Jul. 20, 2013. http://www.nass.usda.gov/Statistics_by_Subject/result.php?682 C946A-BFAA-3ACD-B2F4-6E0652574A9D\&sector=CROPS\& group $=$ FIELD $\% 20$ CROPS\&comm $=$ SOYBEANS.

NRC. 1989. Nutrient Requirements of Dairy Cattle. 6th ed. Natl. Acad. Press, Washington, DC.

NRC. 2001. Nutrient Requirements of Dairy Cattle. 7th ed. Natl. Acad. Press, Washington, DC.

Olmos Colmenero, J. J., and G. A. Broderick. 2006. Effect of dietary crude protein concentration on milk production and nitrogen utilization in lactating dairy cows. J. Dairy Sci. 89:1704-1712.

Pacheco, D., C. G. Schwab, R. Berthiaume, G. Raggio, and H. Lapierre. 2006. Comparison of net portal absorption with predicted flow of digestible amino acids: Scope for improving current models? J. Dairy Sci. 89:4747-4757.

Park, C. S., P. T. Chandler, and R. M. Clark. 1976. Optimum amino acid complement for protein synthesis by rat mammary cells in tissue culture. J. Dairy Sci. 59:1758-1763.

Raggio, G., D. Pacheco, R. Berthiaume, G. E. Lobley, D. Pellerin, G. Allard, P. Dubreuil, and H. Lapierre. 2004. Effect of level of metabolizable protein on splanchnic flux of amino acids in lactating dairy cows. J. Dairy Sci. 87:3461-3472.

Reynolds, C. K. 1995. Quantitative aspects of liver metabolism in ruminants. Pages 351-371 in Ruminant Physiology: Digestion,
Metabolism, Growth, and Reproduction. W. von Engelhardt, S. Leonhard-Marek, G. Breves, and D. Glesecke, ed. Enke, Stuttgart, Germany.

Reynolds, C. K., and N. B. Kristensen. 2008. Nitrogen recycling through the gut and the nitrogen economy of ruminants: An asynchronous symbiosis. J. Anim. Sci. 86:E293-E305.

Rius, A. G., J. A. D. R. N. Appuhamy, J. Cyriac, D. Kirovski, O. Becvar, J. Escobar, M. L. McGilliard, B. J. Bequette, R. M. Akers, and M. D. Hanigan. 2010. Regulation of protein synthesis in mammary glands of lactating dairy cows by starch and amino acids. J. Dairy Sci. 93:3114-3127.

Røjen, B. A., M. Larsen, and N. B. Kristensen. 2012. Effect of abomasal infusion of oligofructose on portal-drained visceral ammonia and urea-nitrogen fluxes in lactating Holstein cows. J. Dairy Sci. 95:7248-7260.

Rulquin, H., S. Rigout, S. Lemosquet, and A. Bach. 2004. Infusion of glucose directs circulating amino acids to the mammary gland in well-fed dairy cows. J. Dairy Sci. 87:340-349.

Sancak, Y., L. Bar-Peled, R. Zoncu, A. L. Markhard, S. Nada, and D. M. Sabatini. 2010. Ragulator-rag complex targets to the lysosomal surface and is necessary for its activation by amino acids. Cell 141:290-303.

Sarbassov, D. D., S. M. Ali, D.-H. Kim, D. A. Guertin, R. R. Latek, H. Erdjument-Bromage, P. Tempst, and D. M. Sabatini. 2004. Rictor, a novel binding partner of mTOR, defines a rapamycin-insensitive and Raptor-independent pathway that regulates the cytoskeleton. Curr. Biol. 14:1296-1302.

Schwab, C. G., C. K. Bozak, N. L. Whitehouse, and M. M. A. Mesbah. 1992. Amino acid limitation and flow to duodenum at four stages of lactation. 1. Sequence of lysine and methionine limitation. J. Dairy Sci. 75:3486-3502.

Sharma, A. K., and D. Chowdhury. 2011. Stochastic theory of protein synthesis and polysome: Ribosome profile on a single transcript. J. Theor. Biol. 289:36-46.

Shennan, D. B., I. D. Millar, and D. T. Calvert. 1997. Mammary-tissue amino acid transport systems. Proc. Nutr. Soc. 56:177-191.

St-Pierre, N. R. 2012. The costs of nutrients, comparison of feedstuffs prices and the current dairy situation. The Ohio State University Extension Buckeye News. Accessed Jul. 20, 2013. http://dairy. osu.edu/bdnews/Volume\% 2014\%20issue\%206/Volume\%2014\%20 Issue $\% 206 . h t m l \#$ Costs.

Stewart, K. W., G. J. S. Cooper, and S. R. Davis. 2009. Coordination of mammary metabolism and blood flow after refeeding in rats. J. Dairy Sci. 92:1543-1553.

Stump, C. S., K. R. Short, M. L. Bigelow, J. M. Schimke, and K. S. Nair. 2003. Effect of insulin on human skeletal muscle mitochondrial ATP production, protein synthesis, and mRNA transcripts. Proc. Natl. Acad. Sci. USA 100:7996-8001.

Toerien, C. A., D. R. Trout, and J. P. Cant. 2010. Nutritional stimulation of milk protein yield of cows is associated with changes in phosphorylation of mammary eukaryotic initiation factor 2 and ribosomal S6 kinase 1. J. Nutr. 140:285-292.

Tuller, T., A. Carmi, K. Vestsigian, S. Navon, Y. Dorfan, J. Zaborske, T. Pan, O. Dahan, I. Furman, and Y. Pilpel. 2010. An evolutionarily conserved mechanism for controlling the efficiency of protein translation. Cell 141:344-354.

USDA-ERS (USDA Economic Research Service). 2012. Livestock, Dairy, and Poultry Outlook: August 2012. Accessed Jul. 20, 2013 http://www.ers.usda.gov/publications/ldpm-livestock,-dairy,-andpoultry-outlook/ldpm218.aspx\#.Uz2Xt61dXwg.

Vanhatalo, A., T. Varvikko, and P. Huhtanen. 2003. Effects of casein and glucose on responses of cows fed diets based on restrictively fermented grass silage. J. Dairy Sci. 86:3260-3270.

Vinod, P. K. U., and K. V. Venkatesh. 2009. Quantification of the effect of amino acids on an integrated mTOR and insulin signaling pathway. Mol. Biosyst. 5:1163-1173.

von Liebig, J. 1863. The Natural Laws of Husbandry. Walton \& Maberly, London, UK.

Wek, R. C., H.-Y. Jiang, and T. G. Anthony. 2006. Coping with stress: eIF2 kinases and translational control. Biochem. Soc. Trans. 34:7-11. 
Wek, S. A., S. Zhu, and R. Wek. 1995. The histidyl-tRNA synthetaserelated sequence in the eIF-2 alpha protein kinase GCN2 interacts with and is required for activation in response to starvation for different amino acids. Mol. Cell. Biol. 15:4497-4506.

Whitelaw, F. G., J. S. Milne, E. R. Ørskov, and J. S. Smith. 1986. The nitrogen and energy metabolism of lactating cows given abomasal infusions of casein. Br. J. Nutr. 55:537-556.

Wickersham, T. A., E. C. Titgemeyer, R. C. Cochran, and E. E. Wickersham. 2009. Effect of undegradable intake protein supplementation on urea kinetics and microbial use of recycled urea in steers consuming low-quality forage. Br. J. Nutr. 101:225-232.
Wickersham, T. A., E. C. Titgemeyer, R. C. Cochran, E. E. Wickersham, and D. P. Gnad. 2008. Effect of rumen-degradable intake protein supplementation on urea kinetics and microbial use of recycled urea in steers consuming low-quality forage. J. Anim. Sci. 86:3079-3088.

Wickramasinghe, S., G. Rincon, A. Islas-Trejo, and J. Medrano. 2012. Transcriptional profiling of bovine milk using RNA sequencing. BMC Genomics 13:45.

Wolfe, A. H., and J. A. Patz. 2002. Reactive nitrogen and human health: Acute and long-term implications. Ambio 31:120-125. 